\title{
ESTRUTURA FUNDIÁRIA DO ESTADO DE GOIÁS - 2003
}

\author{
LAND TENURE STRUCTURE OF GOIAS STATE - 2003 \\ LA STRUCTURE AGRAIRE DE L'ETAT DE GOIÁS - 2003 \\ Antônio Teixeira Neto - Universidade Federal de Goiás - Goiânia - Goiás - Brasil \\ netomap@hotmail.com
}

\begin{abstract}
Resumo
0 artigo tece considerações acerca da estrutura fundiária do estado de Goiás tendo como foco dados secundários e o mapeamento dos módulos fiscais na escala municipal. Tal estrutura fundiária não é muito diferente do que ocorre em regiões e municípios pouco povoados em que a grande propriedade, apesar de pouco numerosa, ocupa a maior parte das áreas rurais estaduais.

Palavras-chave: Goiás, questão fundiária, módulo fiscal.
\end{abstract}

\section{Abstract}

The article weaves considerations about agrarian structure of Goias state, having secondary data and the mapping of fiscal modules in municipal scale as center of the analysis. Such land tenure structure is not lots of different than occurs in regions and municipalities scarcely populated in which the large estate, despite to belittle quantity, occupies the greatest part of the state rural areas.

Key words: Goiás, land tenure issue, fiscal module.

\section{Resumé}

Cet article présente des réflexions sur la structure agraire de l'Etat de Goiás avec un accent sur des données secondaires et la cartographie des modules fiscale au niveau municipal. Cette structure agraire n'est pas très différent de ce qui se passe dans les régions et et les municipalités peu peuplés, où la grande propriété, bien que petite en nombre, occupe la plupart des zones rurales de l'état.

Mots-clés: Goiás, le régime foncier, le module fiscale.

Introdução

Quando nos deparamos com um conjunto de dados como os expostos neste artigo, o primeiro impulso do pesquisador é procurar descobrir as correlações entre número de propriedades e as áreas de cada uma delas, a partir de determinado recorte tipológico - se pequena, média ou grande propriedade -, de sua função produtiva - se destinada à agricultura, à pecuária ou a ambas as atividades - ou segundo outros critérios - se de natureza familiar, se de natureza privada ou se organizada em forma de cooperativa. Além dessas correlações daremos ênfase à informação técnica (organização das propriedades rurais a partir de recortes tipológicos adotados pelo INCRA) e nos dados secundários, o que permitirá o mapeamento na escala municipal. Também comparece na análise uma 
caracterização das regiões goianas, perspectiva já assinalada em outros trabalhos, a exemplo de Teixeira Neto (1982) e Gomes, Teixeira Neto \& Sales (2004).

\section{0 conjunto de dados}

Originalmente, os dados fornecidos pelo INCRA e organizados pela SEPLAN-GO(2003) enumeram apenas os módulos fiscais, a quantidade de propriedades segundo o tamanho e respectivas áreas em cada um dos municípios goianos. Segundo o INCRA (2011), módulo fiscal é a unidade de medida expressa em hectares, fixada para cada município, considerando os seguintes fatores:

- tipo de exploração predominante no município; renda obtida com a exploração predominante;

- outras explorações existentes no município que, embora não predominantes, sejam significativas em função da renda ou da área utilizada;

- conceito de propriedade familiar.

Assim, para o INCRA, o módulo fiscal serve de parâmetro para classificação do imóvel rural quanto ao tamanho da propriedade. Conforme consta na Lei n. 8.629, de 25/02/1993 (BRASIL, 1993), a distribuição das propriedades por tamanho é feita da seguinte forma:

- pequena propriedade: imóvel rural com área de até 4 (quatro) módulos fiscais; - média propriedade: imóvel rural de área superior a 4 (quatro) e até 15 (quinze) módulos fiscais;

- grande propriedade: acima de 15 módulos fiscais.

O módulo fiscal serve também para definir os beneficiários do PRONAF (Programa Nacional de Fortalecimento da Agricultura Familiar), em que se enquadram os pequenos agricultores de economia familiar, proprietários, meeiros, posseiros, parceiros ou arrendatários de até 4 módulos fiscais. Finalmente, para dirimir dúvidas quanto ao que vem a ser, respectivamente, módulo rural e módulo fiscal, o INCRA (2011) assim define os dois termos:

módulo rural é calculado para cada imóvel rural em separado, e sua área reflete o tipo de exploração predominante no imóvel, segundo 
sua região de localização; módulo fiscal, por sua vez, é estabelecido para cada município, e procura refletir a área mediana dos módulos rurais dos imóveis rurais do município. (p. ????)

Esse conjunto de definições, somados às informações sobre a diversidade regional do território goiano, permitiram uma visão da estrutura fundiária desse território.

\section{Análise dos dados}

A análise será desenvolvida a partir dos dados agrupados nas figuras 9 a 32, constante no anexo do artigo. A anotação do INCRA foi feita com base no módulo fiscal de cada município. Segundo este critério, a pequena propriedade é, por exemplo, aquela que possui até 4 módulos fiscais. Isto significa que em todos os municípios do Estado de Goiás ela varia de “0 - 4 módulos fiscais”. Nesta linha de raciocínio, a classificação das propriedades segundo as categorias pequena, média e grande variam de município para município e de região para região, pois os módulos fiscais também variam em cada um dos municípios e em cada uma das regiões. Em Uruaçu, por exemplo, o módulo fiscal é de 50 ha e em Abadia de Goiás ele é de 24 ha. Isto significa que, em Uruaçu, a pequena propriedade pode chegar até a 200 ha $(50 \times 4=200)$. Em Abadia de Goiás ela chegaria apenas a 96 ha ( 24 x $4=96$ ha). Na verdade, os dados mostram que em Uruaçu a pequena propriedade tem em média 62,14 ha (área total das pequenas propriedades, que é de 64.994 ha, dividida pelo total das pequenas propriedades, que é de 1.046). Calculando-se o tamanho da pequena propriedade em módulos fiscais, em Uruaçu ela teria 1,24 módulos em média $(62,14 / 50=1,24)$. Por seu lado, em Abadia de Goiás, a pequena propriedade tem em média apenas 28,98 ha (área total das pequenas propriedades, que é de 3.970 ha, dividida pelo total das pequenas propriedades, que é de 137). O tamanho médio das pequenas propriedades em módulos fiscais em Abadia de Goiás é de 1,21 módulos $(28,98 / 24=1,21)$. Para o conjunto do estado de Goiás, o tamanho médio da pequena propriedade é de 48,48 ha $(4.995 .048$ ha/103.035 pequenas propriedades $=48,48)$. Em módulos fiscais, o tamanho médio da pequena propriedade, como, aliás, acontece na maior parte dos municípios, das microrregiões e mesorregiões goianos, é maior que 1 e menor que 2, ou seja, é de 1,28 módulos, muito próximo, por exemplo, do que é em Uruaçu (1,24 módulos), Abadia de Goiás (1,21 
módulos), microrregiões de Catalão (1,40 módulos), Anicuns (1,25 módulos), Entorno de Brasília (1,2 módulos), Goiânia (1,34 módulos), Vão do Paranã (0,97 módulo), Porangatu (1,37 módulos), São Miguel do Araguaia (1,49 módulos).

Porém, como já observado, isso não significa que nos municípios, nas microrregiões e mesorregiões, a pequena propriedade tenha, em hectares, tamanhos mais ou menos idênticos, quando considerados em módulos fiscais, porque estes últimos, como se viu, variam de município para município e, obviamente, de região para região. Na microrregião do Vão do Paranã, por exemplo, a pequena propriedade, que não chega a 1 módulo fiscal (0,97 módulo), tem, em média, 67,7 hectares $(0,97 \times 70=$ 67,7). Considerando o recorte municipal, no município de Mambaí a pequena propriedade tem, em média, 42,7 ha (0,61 módulo), no de Posse 53,2 ha (0,76 módulo fiscal), no de São Domingos, 79,1 ha (1,13 módulos) e no de Flores de Goiás, 123,2 ha (1,76 módulos). Em microrregiões bastante urbanizadas, como a de Goiânia, o tamanho médio da pequena propriedade é 28,6 ha (1,34 módulos), entretanto, em municípios em que o módulo fiscal é de apenas 7 hectares - Goiânia e Senador Canedo -, a pequena propriedade tem, em média, 9,73 ha (1,39 módulos) e 11,97 ha (1,71 módulos), respectivamente. Enfim, no conjunto dos municípios goianos, o tamanho médio das pequenas propriedades em módulos fiscais varia pouco, mas, em microrregiões, como a de São Miguel do Araguaia, por exemplo, em que a pecuária predomina como atividade econômica, a pequena propriedade, em média, é relativamente grande: 91,69 ha (1,49 módulos).

Mesmo em microrregiões, como a do Sudoeste Goiano, que, até recentemente, era caracterizada por uma economia rural baseada na criação de gado, mas, atualmente, está voltada essencialmente para a agricultura praticada em grandes empreendimentos rurais, a pequena propriedade ainda é, em média, relativamente grande: 65,52 ha (1,55 módulos). O município de Rio Verde, em que se pratica atualmente uma agricultura de alta tecnologia, a reconversão econômica - passagem da pecuária tradicional para a moderna agricultura -, indica que a propriedade tende a se esfacelar, pois, a pequena propriedade é menor que a média microrregional: 48,28 ha (1,61 módulos). ${ }^{1}$

No que tange ao tamanho médio do módulo fiscal em hectares em cada uma das microrregiões e mesorregiões, verifica-se, por exemplo, que na microrregião de Porangatu, da qual Uruaçu faz parte, o módulo fiscal 
médio é 54,5 ha, na mesorregião Norte Goiano (composta das microrregiões de Porangatu e Chapada dos veadeiros), o módulo fiscal medido é de 59,8 ha, o que, também reflete nos tamanhos médios da pequena, da média e da grande propriedade da mesorregião: 78,8 ha, 456 ha e 1.848 ha, respectivamente. Entre todos os municípios e todas as microrregiões goianos, os maiores módulos fiscais são os dos municípios pouco povoados de Campos Belos e Monte Alegre de Goiás, na Chapada dos Veadeiros (80 ha) e de todos os municípios do Vão do Paranã (70 ha). Por seu lado, o Vale do São Patrício é essencialmente marcado pelo pequeno tamanho de sua propriedade rural. Isto decorre, talvez, do fato de se ter realizado ali o primeiro projeto de colonização com famílias de camponeses brasileiros assentadas em propriedades de 100 hectares em média. Ainda hoje, na microrregião de Ceres, a propriedade rural tem, em média, 104 há; porém, tanto as pequenas, como as médias e grandes propriedades têm áreas pequenas se comparadas à média do estado para cada uma das três categorias de propriedade: 32,8 ha (contra 48,50 ha), 190,8 ha (contra 291,80 ha) e 868,8 ha (contra 1.391,50 ha), respectivamente. Outras comparações surgem quando se confrontam os dados. Os municípios, as microrregiões e as mesorregiões em que, respectivamente, os módulos fiscais têm os menores valores são aqueles situados em volta de Goiânia: Goiânia e Senador Canedo (7 ha), e Anápolis, Bonfinópolis, Campo Limpo de Goiás e Leopoldo de Bulhões (16 ha).

Até aí, compreende-se o porquê desse padrão fundiário. Mas, soa contraditório um município, como o de Campo Alegre de Goiás (com 3.119 quilômetros quadrados, cuja economia agropecuária é tradicionalmente praticada sobre grandes propriedades), possuir um módulo fiscal de apenas 28 ha, inferior, por exemplo, aos módulos fiscais de Anhanguera (45 ha) - o menor município goiano, com apenas 56,6 quilômetros quadrados -, de Ipameri e Catalão (40 h) - que têm as mesmas características agropecuárias de Campo Alegre de Goiás - e de Bela Vista de Goiás e Hidrolândia (35 ha), localizados no aglomerado urbano de Goiânia, que como Rio Quente - município eminentemente turístico próximo a Caldas Novas, na microrregião do Meia Ponte, cujo módulo fiscal é de 45 ha -, são extremamente pressionados pela especulação imobiliária.

Viu-se acima que a anotação do INCRA, no que diz respeito à área (em hectares) de cada uma das categorias de propriedades, não foi feita a partir de recortes absolutos válidos para todos os municípios goianos. Por 
exemplo: até 100 ha (pequena propriedade); + de 100 até 1.000 ha (média propriedade); + de 1.000 ha (grande propriedade). Em decorrência dessa particularidade, é, pois, impossível comparar, município por município, cada uma das categorias de propriedades entre si a partir de um recorte, digamos, universal, como o acima exemplificado. Isto só é realizável a partir das categorias "pequena", "média” e "grande”, independentemente das áreas de cada uma delas em cada município.

Tomando o estado de Goiás como um todo, vê-se que o módulo fiscal, em 2003, tinha em média 37,9 ha e que as propriedades rurais podem assim ser resumidas na síntese da Figura 1.

Figura 1 - Goiás - Estrutura fundiária, 2003

\begin{tabular}{|c|c|c|c|c|c|c|c|c|c|c|c|c|c|}
\hline \multicolumn{2}{|c|}{ Propriedades } & \multicolumn{4}{|c|}{ Pequena propriedade } & \multicolumn{4}{|c|}{ Média propriedade } & \multicolumn{4}{|c|}{ Grande propriedade } \\
\hline (0T) & $\begin{array}{l}\text { Área } \\
\text { (ha) }\end{array}$ & (0T) & $(\%)$ & $\begin{array}{r}\text { Área } \\
\text { (ha) }\end{array}$ & $(\%)$ & (OT) & $(\%)$ & $\begin{array}{r}\text { Área } \\
\text { (ha) }\end{array}$ & (\%) & (OT) & $(\%)$ & $\begin{array}{c}\text { Área } \\
\text { (ha) }\end{array}$ & $(\%)$ \\
\hline 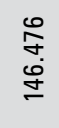 & 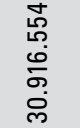 & 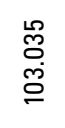 & 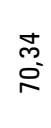 & 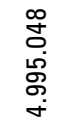 & $\bar{\emptyset}$ & $\frac{\text { 号 }}{\frac{\pi}{\pi}}$ & $\underset{ָ}{\mathbb{N}}$ & 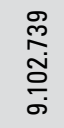 & ন্ & $\begin{array}{l}\infty \\
\stackrel{\infty}{\infty} \\
\stackrel{\text { I }}{ }\end{array}$ & $\stackrel{\infty}{\stackrel{\infty}{0}}$ & $\begin{array}{l}\hat{\infty} \\
\infty \\
\infty \\
\infty \\
0\end{array}$ & 吉 \\
\hline
\end{tabular}

Fonte: INCRA, 2003.

Em 1996, conforme dados organizados pela SEPLAN-GO (GOIÁS, 1996), a estrutura fundiária do estado de Goiás, segundo o tamanho das propriedades, mostrava que a situação no campo era bem diferente da observada hoje, como se pode verificar na Figura 2.

Figura 2 - Goiás - Estrutura Fundiária, 1996

\begin{tabular}{|c|c|c|c|c|c|c|c|c|c|c|c|c|c|}
\hline \multicolumn{2}{|c|}{ Propriedades } & \multicolumn{4}{|c|}{ Pequena propriedade } & \multicolumn{4}{|c|}{ Média propriedade } & \multicolumn{4}{|c|}{ Grande propriedade } \\
\hline (OT) & $\begin{array}{l}\text { Área } \\
\text { (ha) }\end{array}$ & (OT) & $(\%)$ & $\begin{array}{l}\text { Área } \\
\text { (ha) }\end{array}$ & (\%) & (OT) & $(\%)$ & $\begin{array}{l}\text { Área } \\
\text { (ha) }\end{array}$ & $(\%)$ & (OT) & $(\%)$ & $\begin{array}{l}\text { Área } \\
\text { (ha) }\end{array}$ & $(\%)$ \\
\hline$\frac{\bar{\sigma}}{\stackrel{5}{\equiv}}$ & 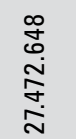 & 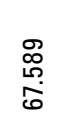 & $\begin{array}{l}0 \\
0 \\
0\end{array}$ & 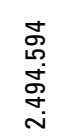 & $\bar{\sigma}$ & 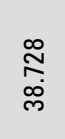 & $\begin{array}{l}\text { ¿ } \\
\text { ले }\end{array}$ & 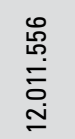 & $\hat{\tilde{g}}$ & 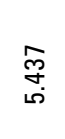 & \begin{tabular}{l}
$\mathscr{\infty}$ \\
\multirow{\sigma}{*}{}
\end{tabular} & 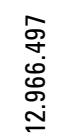 & $\underset{\mathcal{F}}{\mathcal{F}}$ \\
\hline
\end{tabular}

Fonte: INCRA, 2003.

Na Figura 3 podemos verificar os tamanhos médios das propriedades segundo as três categorias em 2003 e 1996. 
Figura 3 - Goiás - Tamanho médio das propriedades (ha)

\begin{tabular}{|l|c|c|}
\hline Propriedade & $\mathbf{2 0 0 3}$ & $\mathbf{1 9 9 6}$ \\
\hline Pequena propriedade & 48,5 & 36,9 \\
\hline Média propriedade & 291,8 & 310,2 \\
\hline Grande propriedade & $1.391,5$ & $2.384,0$ \\
\hline
\end{tabular}

Fonte: GOIÁS (1996, 2003).

Comparando-se as figuras 1, 2, 3, verifica-se que a estrutura fundiária do estado de Goiás está passando por transformações contraditórias. De um lado, constata-se um aumento expressivo de todas as categorias de propriedades, tanto em quantidades absolutas (QT) como em área (ha), principalmente a pequena propriedade, que muito cresceu em todos os aspectos entre 1996 e 2003, passando de 67.589 para 103.035 estabelecimentos (aumento de 52,4\%), de 2.494.594 ha para 4.495.084 ha (aumento de $80,2 \%$ ) de área total, de 36,9 ha para 48,5 ha de tamanho médio (aumento de $31,4 \%$ ). Disso se conclui que a média propriedade - que, como a pequena, é também de caráter eminentemente familiar -, está perdendo terreno, principalmente para a grande propriedade. No período 19962003, enquanto que a grande propriedade teve um aumento de $122,3 \%$ em número de estabelecimentos e de $29,7 \%$ em termos de área, a média propriedade encolheu $19,5 \%$ em número de estabelecimentos e $24,2 \%$ em sua área total.

O que explicaria esse aumento expressivo da pequena propriedade? Uma hipótese pode, por exemplo, ser aventada: a decomposição de parte da média propriedade em minifúndios, que, como os latifúndios improdutivos, pouca serventia social e econômica têm para seus proprietários. Na verdade, quando a propriedade é minúscula, ela mal sustenta os seus donos e os que dela se servem e, além disto, quando localizadas próximas a áreas fortemente urbanizadas, como o Aglomerado Urbano de Goiânia e o Entorno de Brasília, por exemplo, ficam expostas à especulação imobiliária.

Se dermos crédito aos números, entre 1996 e 2003, em razão da forma como o grande capital invadiu o campo em decorrência do avanço da agricultura comercial e do agronegócio, tanto o número total de propriedades, como suas respectivas áreas, tiveram aumentos significativos, principalmente no que concerne o número de estabelecimentos (QT): $31,03 \%$ e $12,53 \%$, respectivamente. No que tange apenas à área total dos 
estabelecimentos rurais, nesse espaço de sete anos, 3.443.906 ha (34.439 quilômetros quadrados) foram incorporados às propriedades rurais, principalmente em áreas de cerrado. Isto significa que parte da área agricultável do estado encontrava-se não declarada, como que "escondida" do fisco, como se fosse uma imensa reserva de valor, intocada, à espera de seu aproveitamento e de sua incorporação ao espaço produtivo no momento oportuno. Os reflexos negativos de tal situação são evidentes, principalmente sobre a média propriedade, ainda de natureza essencialmente familiar, o que, por exemplo, faz aumentar mais ainda o fosso entre ela e a grande propriedade. Trata-se, contudo, de uma hipótese levantada a partir dos dados acima confrontados, pois, só se conhecerá a realidade dos fatos quando se dispuser de informações mais atualizadas fornecidas pelo próximo censo agropecuário. ${ }^{2}$ Por enquanto, a querela entre os grandes proprietários - ou melhor, os grandes produtores rurais - e os pequenos proprietários, reside em saber quem é mais importante para o bem da economia e da sociedade brasileira: se os primeiros, que foram responsáveis por $87 \%$ da mandioca, $70 \%$ do feijão, $46 \%$ do milho, $38 \%$ do café etc., os quais se voltaram para o mercado externo, ou se os últimos que, com o apoio do PRONAF, buscavam abastecer o mercado interno.

Ponderações feitas, conclui-se que a análise da informação em valores absolutos fica prejudicada, pois em determinados municípios uma propriedade de 200 ha (ou 4 módulos, como é o caso de Uruaçu) é classificada como "pequena”, em outros (como é o caso do município de Goiânia), ela é classificada como "grande" (aqui, o módulo fiscal é de apenas 7 ha, contra 50 ha em Uruaçu). Por outro lado, se na realidade o que importa é realçar o caráter tipológico da propriedade - se "grande", "média" e "pequena" - e o seu peso relativo em cada município, sua expressão em módulos fiscais mostra melhor a realidade da estrutura fundiária local. Se a comparação se realizar a partir de recortes válidos para todos os municípios, como logo acima observado, a média e a grande propriedade praticamente inexistiriam nos municípios, microrregiões e mesorregiões em que o módulo fiscal corresponde a poucos hectares (por exemplo, na microrregião de Goiânia e em municípios, como os de Goiânia, Senador Canedo, Abadia de Goiás etc.). Neste caso, quanto à transcrição gráfica dos dados, a grande propriedade seria representada praticamente em branco.

Analisando-se os dados a partir do município, descobrem-se certas particularidades. Há, por exemplo, indícios de que a área (ha) referente 
à pequena propriedade no município de Goiás tenha sido "esquecida" no momento da construção da tabela de dados. Mas, com relação ao número de propriedades, a mesma tabela mostra que, de fato, existem 1.520 pequenas propriedades, o que pressupõe que elas foram cadastradas e, assim, possuem uma determinada área. Qual seria então sua área total? O dado é desconhecido, pois nada consta na tabela do INCRA/SEPLAN. Diante disto, para efeito de comparação, admitiu-se que a área total das pequenas propriedades naquele município corresponde à média estadual (16,1\% da área total das propriedades). Como o total de 241.219 hectares no município corresponde apenas à soma da "média" e "grande" propriedade, atribuiu-se à pequena propriedade uma área de 50.039 ha, ou seja, 16,1\% da área total do município, que é de 310.801 ha. Assim, a área total das propriedades do município passaria de 241.219 ha anotados pelo INCRA/ SEPLAN para 291.258 ha. Na verdade, pode-se observar que, por razões diversas, quando se trata de registrar dados sobre a estrutura fundiária há que se levar em conta que as contas nunca fecham redondamente.

As incoerências (áreas de propriedades rurais maiores que as de alguns municípios, ou, inversamente, demasiadamente pequenas, por exemplo) são numerosas e elas podem explicar muitos aspectos da mal contada história das estatísticas rurais em nosso Estado, como se observar nos exemplos destacados a seguir:

a) Em muitos municípios a diferença entre a área total das propriedades rurais e a área total do município é de tal maneira desencontrada, que leva o leitor a levantar inúmeras hipóteses, como, entre outras, a de que, dada essa diferença, há uma grande área de terras sobrando, como se ainda constituíssem terras devolutas. Ora, sabe-se que, em Goiás, há muito tempo não mais existem terras devolutas, pois, além das áreas urbanizadas, lacustres e ocupadas por cursos d'água de qualquer natureza, áreas públicas e especiais (parques nacionais e estaduais, reservas ecológicas e biológicas, áreas militares e de interesse público etc.), a propriedade do solo é basicamente privada. No conjunto, 9,2\% do território estadual (3.118.287 hectares) constituem terras fora do domínio privado. Sabe-se, porém, que os dois maiores parques nacionais localizados em território goiano pouco passam de 190.000 hectares. Segundo dados fornecidos pelo Anuário Estatístico do Estado de Goiás (2005), as áreas protegidas federais, estaduais e municipais (parques nacionais e estaduais, sobretudo) e áreas urbanizadas chegariam a $\mathbf{1 . 5 0 0 . 0 0 0}$ hectares. Disto resulta que 
outros tantos ou mais hectares (cerca de 15.000 quilômetros quadrados) estariam fora do domínio privado, e não teriam, portanto, donos.

b) Há municípios em que a área das propriedades rurais é bem menor que $70 \%$ da área municipal, o que reforça mais ainda a hipótese de que haja muita terra sobrando em Goiás: Aragarças, no Oeste; Alto Horizonte, Bonópolis, Campinorte, Montividiu do Norte, Niquelândia (no maior município de Goiás, com 9.844 quilômetros quadrados, as propriedades rurais ocupam apenas 43,5\% do território municipal) e Nova Iguaçu de Goiás, no Norte; Nova Roma, na Chapada dos Veadeiros; Buritinópolis, no Vão do Paranã; Cidade Ocidental, Águas Lindas de Goiás, Mimoso de Goiás, Novo Gama, Valparaíso de Goiás e Vila Boa, no Entorno de Brasília; Guarinos, no Vale do São Patrício; Campo Limpo, Jesúpolis e Nova Veneza, na microrregião de Anápolis; Aparecida de Goiânia, Aragoiânia, Bonfinópolis, Caldazinha, Goiânia, Santo Antônio de Goiás e Terezópolis de Goiás, no Aglomerado Urbano de Goiânia; Aparecida do Rio Doce, Castelândia e Santo Antônio da Barra, no Sudoeste Goiano; Campestre e Varjão, no Vale do Rio dos Bois; Inaciolândia e Professor Jamil, no Vale do Rio Meia Ponte; Gameleira de Goiás, Palmelo, Anhanguera, Cumari e Três Ranchos, na Região da Estrada de Ferro. Obviamente, em municípios pequenos situados em volta de Goiânia e Brasília (Aparecida de Goiânia, Novo Gama, Cidade Ocidental, Valparaíso de Goiás, entre outros), a malha urbana, como já observado, ocupa a maior parte da área municipal. Há, contudo, exceções, como Goianira, em que a área das propriedades rurais ultrapassa a área municipal em 19\%. Diante disto, pergunta-se: naqueles municípios, a quem pertencem os $30 \%$, ou mais, restantes? Só no município de Niquelândia estariam sobrando cerca de 5.500 quilômetros quadrados, ou seja, 550.000 hectares. Observa-se que não se trata de municípios, como os de Mineiros, Cavalcante, Alto Paraíso de Goiás, Caldas Novas, Goiás etc., que abrigam áreas institucionais inalienáveis (parques nacionais e estaduais, por exemplo).

c) Em praticamente todas as microrregiões goianas, principalmente aquelas em que a atividade agropecuária é a base da economia - Vale do Rio dos Bois, Meia Ponte, Sudoeste Goiano, Quirinópolis, São Miguel do Araguaia, Rio Vermelho etc. -, o número de municípios em que as áreas das propriedades rurais ultrapassam as dos municípios é relativamente grande: Acreúna, Edealina, Edéia, Palminópolis, Paraúna, Turvelândia, Aloândia, Bom Jesus de Goiás, Joviânia, Mairipotaba, Mundo Novo, 
Nova Crixás, Britânia, Jussara, Santa Fé de Goiás, Aporé, Jataí, Mineiros, Montividiu, Palestina de Goiás, Rio Verde, Santa Helena de Goiás, Santa Rita do Araguaia, Caçu, Quirinópolis etc. Isto sem contar que, em cerca de 30 municípios, as áreas das propriedades rurais somam mais de 95\% das áreas municipais, sobrando pouca coisa para as áreas urbanizadas, as reservas legais, os rios e lagos e até mesmo as APAs. Mas é no Norte Goiano e no Vão do Paranã que, além de Uruaçu, Mutunópolis, Trombas e Buritinópolis, Mambaí e Simolândia, cujas áreas municipais são menores que as áreas das propriedades rurais, registram-se as duas maiores aberrações dessas estatísticas: em Mara Rosa, a área municipal é 65\% menor que a das propriedades rurais e em Sítio d'Abadia ela chega a 69\%! Só pode ser erro de anotação, caso contrário não há como realizar análises e estudos corretos sobre a estrutura fundiária do estado, pelo menos no que tange ao tamanho das propriedades rurais em cada município.

d) Coincidentemente, nos quatro últimos municípios criados em Goiás em 1997 (Ipiranga de Goiás, desmembrado de Ceres, Campo Limpo de Goiás, desmembrado de Anápolis, Gameleira de Goiás, desmembrado de Silvânia, e Lagoa Santa, desmembrado de Itajá) os dados são completamente disparatados ou inexistem, como é o caso de Lagoa Santa. Em Ipiranga de Goiás, por exemplo, cuja área municipal é de 24.146 hectares, só existem cadastrados 18 imóveis rurais, cujas áreas perfazem apenas 346 hectares (média de 19 hectares para cada um)! Sabe-se que o município é essencialmente agrícola, o que pressupõe que o número de propriedades deve ser significativo. Além do mais, por situar-se no centro da antiga Colônia Agrícola de Goiás, em que a propriedade é marcadamente familiar, é de se supor que se trata de erro evidente, seja de cadastramento das propriedades, seja de omissão de informação por parte dos proprietários. Por quê? Porque no município de Ceres, de quem Ipiranga de Goiás se emancipou, o parcelamento da terra é o mais significativo de todo o Vale do São Patrício - 90,8 \% dos 675 imóveis rurais cadastrados constituem pequenas propriedades. Ele é também um dos poucos municípios goianos em que a pequena propriedade representa mais da metade (57,7\%) de toda a sua área rural. Em Campo Limpo de Goiás, cuja área municipal é de 15.620 hectares, existem apenas 8 propriedades cadastradas (6 pequenas e 2 médias), cujas áreas perfazem apenas 472 hectares. Em Gameleira de Goiás, apenas 7,6\% da área municipal (5.516 hectares) estão cadastrados como propriedades rurais. De onde vêm essas incoerências? Não tenho respostas para isto. 


\section{Espacialização dos dados}

Para a realização dos mapas, o critério utilizado foi simples: para cada uma das categorias de propriedade (grande, média, pequena) realizou-se um diagrama de distribuição das porcentagens de cada município para se determinar os agrupamentos (grupos de porcentagens) de municípios que esta construção gráfica permite. O número de agrupamentos é o mesmo para todos os mapas, fato que facilita a percepção e a comparação visual das diferentes categorias de propriedade, bem como sua repartição espacial.

Assim determinados, os grupos de valores quantitativos (no caso, grupos de porcentagens) são transcritos no mapa através de círculos ordenados, fato que favorece a percepção imediata deste ou daquele município, segundo a importância que nele representa a pequena, média ou grande propriedade - se ela é expressiva, ou não, por exemplo -, a região em que ele se situa e muitas outras correlações espaciais e quantitativas. Este, aliás, é o papel fundamental do mapa ou de qualquer outra construção gráfica: reduzir a agrupamentos significativos a informação exaustiva e detalhada expressa pela tabela de dados. No caso presente, trata-se de uma tabela comportando 246 municípios, 18 microrregióes, 5 mesorregiões e 1 estado, totalizando 270 objetos geográficos afetados a 17 caracteres quantitativos (tamanho do módulo fiscal, número total de propriedades, área das propriedades.), o que perfaz 4.590 dados elementares ( $270 \times 17=4.590)$.

Outros mapas, além destes, podem ser elaborados para, entre outros aspectos, realçar a quantidade absoluta de hectares e de pequenas, médias e grandes propriedades em cada município. Porém, como estas iriam apenas mostrar o óbvio: que, em geral, os municípios maiores têm quantidades maiores de hectares, que as pequenas propriedades são mais numerosas que todas as outras categorias juntas e assim por diante. Quem se interessar por detalhes particulares da informação - por exemplo, quantos hectares têm as pequenas, médias e grandes propriedades no município de Uruaçu, ou qual o número de grandes propriedades em todo o Norte Goiano? -, basta consultar a tabela de dados. Vejamos agora os comentários resumidos sobre cada uma das figuras:

Figura 4 (mapa dos módulos fiscais) - De um modo geral, nos municípios e regiões em que o módulo fiscal é grande, o tamanho da propriedade também é grande e grande é também a área ocupada por elas. Independentemente do critério utilizado para a construção da tabela de 
Figura 4

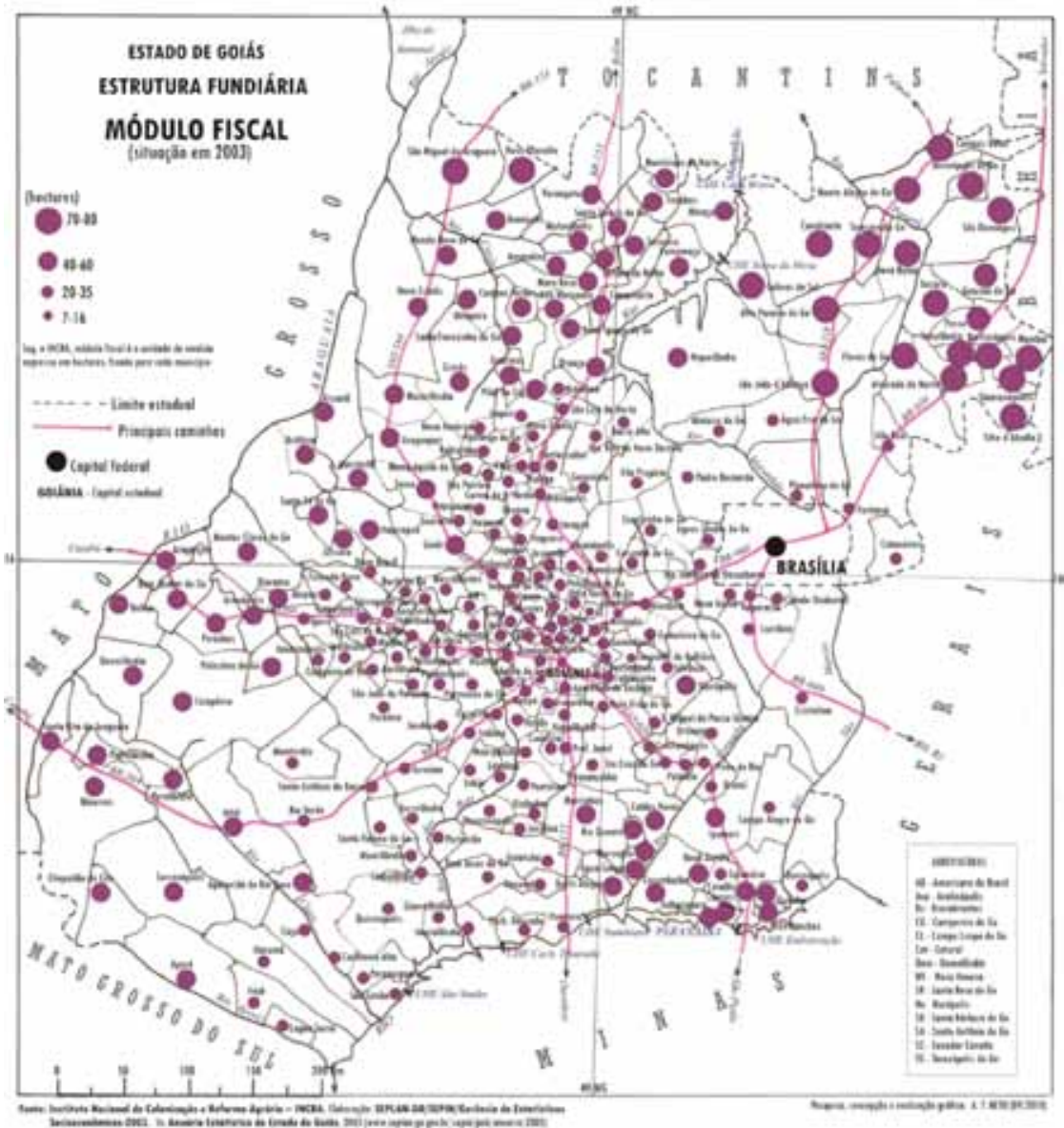

dados numéricos e dos mapas, tanto uma quanto outra das construções mostra o que universalmente é uma constante: a pequena propriedade é obviamente mais numerosa que a média e a grande, mas é esta última que, no conjunto do estado, engloba mais da metade da área total das propriedades (54,4\%), embora em números ela represente apenas $8,2 \%$ do total de propriedades, contra $70,5 \%$ para a pequena. É esta relação - pequeno número de grandes propriedades inversamente proporcional à área ocupada por elas - que de maneira simples determina o caráter concentrado, ou mais democraticamente distribuído, da terra. 
Figura 5 (mapa das pequenas propriedades) - Geralmente, a pequena propriedade é mais expressiva nas regiões de maior densidade urbana e demográfica, principalmente no entorno de Goiânia e de Brasília, no Vale do São Patrício e nas regiões turísticas de Três Ranchos e Caldas Novas. Algumas exceções, contudo, se confirmam, como, entre outras, um número expressivo de pequenas propriedades em pequenos municípios Buritinópolis, Damianópolis e Nova Roma, por exemplo - localizados em regiões em que a propriedade é tradicionalmente grande e concentrada. Por outro lado, nas antigas áreas em que se criava gado extensivamente,

Figura 5

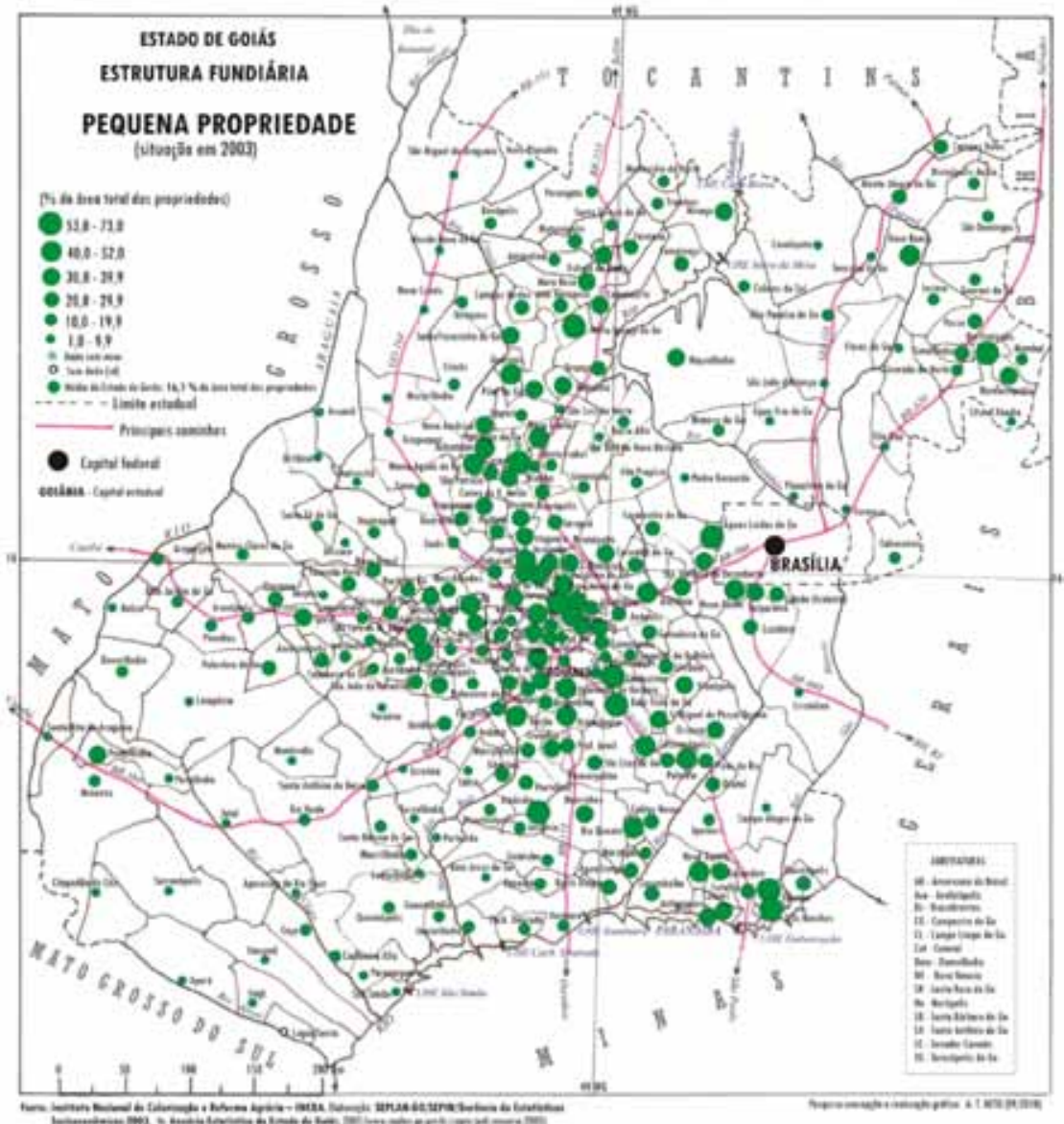


como o Sudoeste Goiano, e nas áreas ainda pouco povoadas - Chapada dos Veadeiros e todo o Vale do Araguaia - a pequena propriedade é ainda pouco expressiva - e tende a continuar sendo em decorrência de sua cooptação pelo agronegócio, que exige grandes áreas para a implantação de projetos agropecuários de alta tecnologia.

Figura 6 (mapa das médias propriedades) - A mesma tendência se observa com relação à média propriedade: ela é mais expressiva onde a pequena propriedade é também expressiva, ou seja, nas regiões mais povoadas e naquelas situadas em volta das duas metrópoles do cerrado

Figura 6

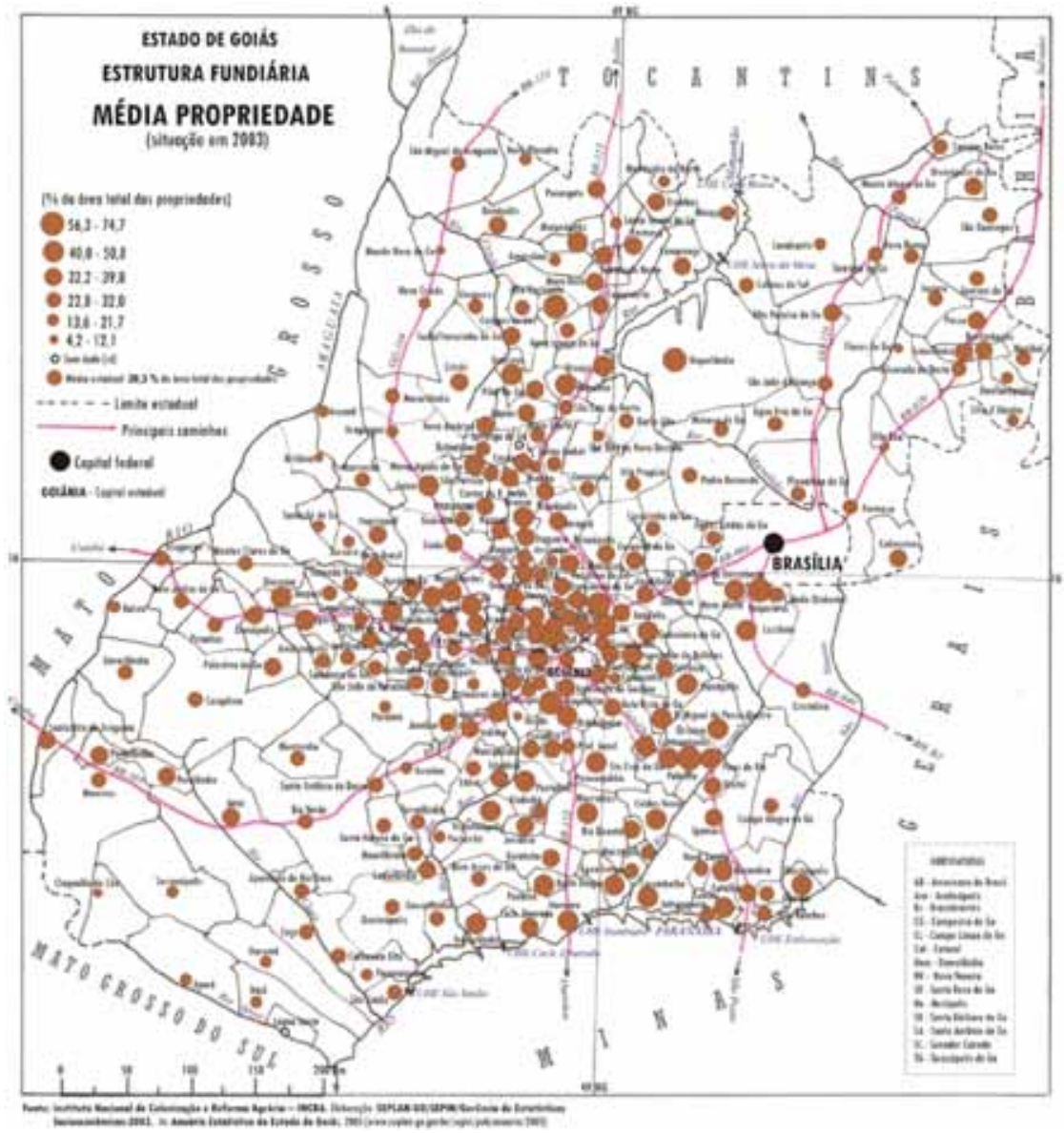


- Goiânia e Brasília, respectivamente. Do mesmo modo que a pequena propriedade, ela é também expressiva no Vale do São Patrício, em torno de Ceres, ao longo da "Belém-Brasília" (BR-153) e em volta de Pires do Rio e Catalão.

Figura 7 (mapa das grandes propriedades) - A grande propriedade predomina nas margens do território, ou seja, nas regiões de um lado e outro do grande corredor rodoviário constituído pela BR-153 (vales do Araguaia, do Maranhão e do Paranã) e todo o Sudoeste Goiano. Porém, chama a atenção um fato, à primeira vista contraditório: o número expressivo de

Fidura 7

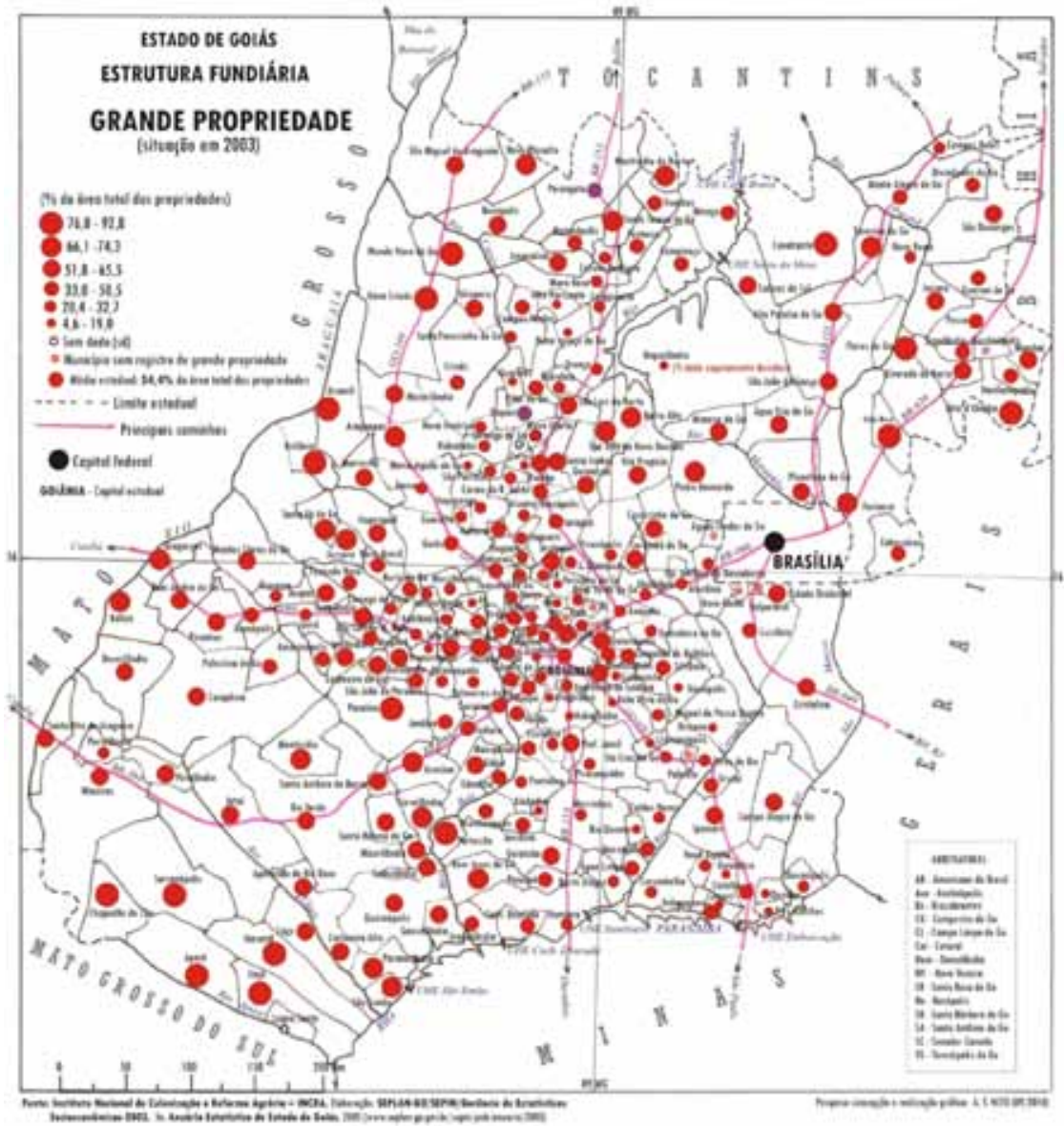


grandes propriedades em pequenos municípios do Entorno de Goiânia e de Brasília, como, entre outros, Senador Canedo, Goianápolis e Santo Antônio de Goiás, localizados nas áreas metropolitanas de Goiânia, e Cidade Ocidental, próximo a Brasília.

A Figura 8 (matriz ponderada) - Trata-se na realidade de um gráfico de entrada dupla, no qual os dados (em porcentagens) são transcritos e lidos, por categoria e por microrregião, ao longo dos eixos das abcissas (x) - a área dos estabelecimentos - e das ordenadas (y) - a quantidade de estabelecimentos. A média estadual é mostrada em destaque visual.

Figura 8

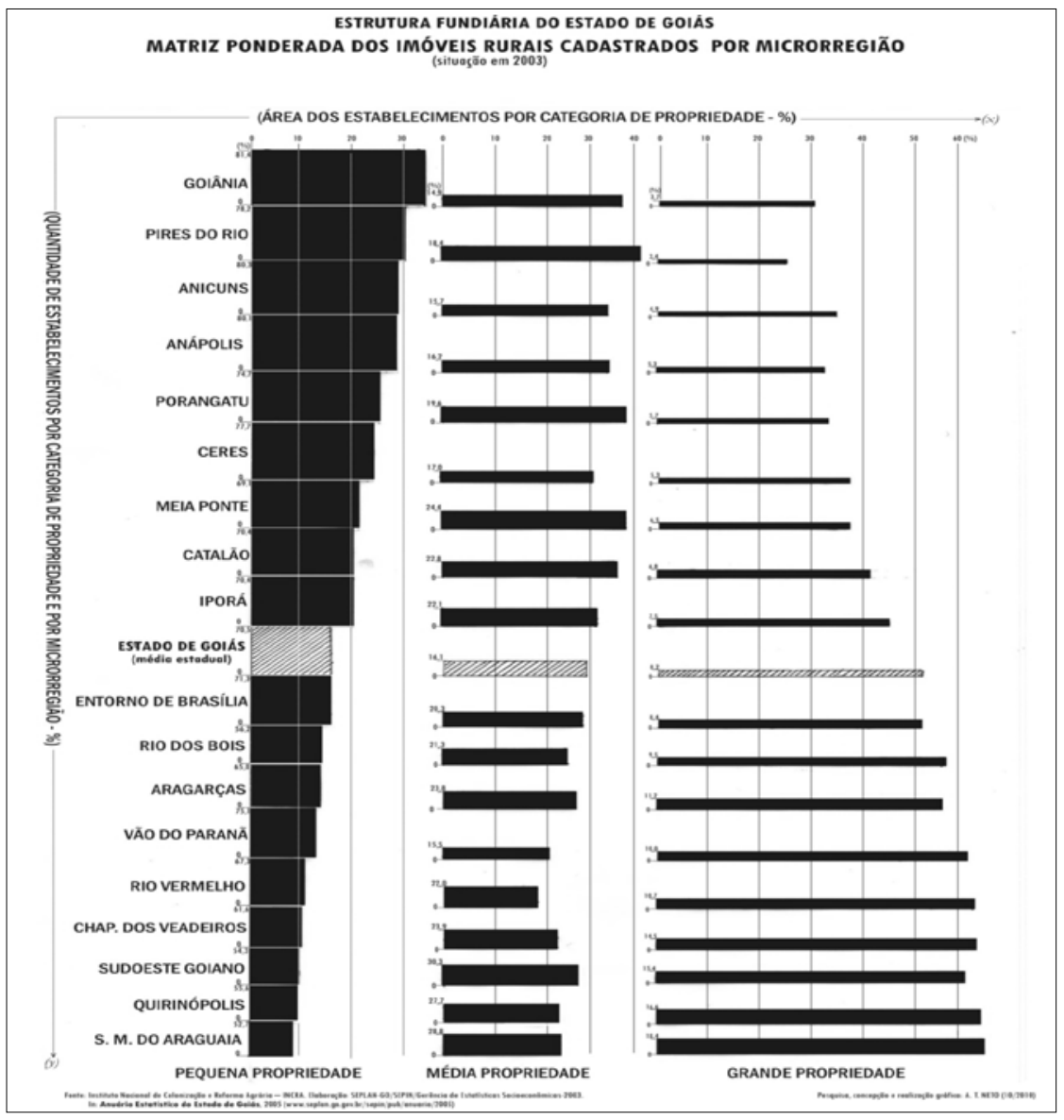


No tratamento gráfico da informação dá-se a este tipo de construção o nome de "matriz ponderada", ou "diagrama ponderado", pelo fato de transcrever duas informações significativas ao mesmo tempo - no caso, os dados relativos ao peso de cada uma das categorias de propriedade rural, segundo as microrregiões. Nota-se que em construções gráficas como esta, a área de cada diagrama é significativa e chama a atenção do leitor, fato que permite comparações rápidas, tanto em linha (x), como em coluna (y).

Nesta, digamos, "síntese" - na realidade, trata-se de dezenove diagramas ponderados dispostos no plano em forma de matriz -, a informação já é bastante generalizada, pois, os dados dos 246 municípios goianos foram reduzidos a 18 grupos de municípios, que são as microrregiões. Outros níveis de "síntese" poderiam ainda ser considerados, como, por exemplo, a representação dos dados por mesorregiões, reduzindo mais ainda a informação. Porém, qualquer que seja o grau de generalização levado em conta, os diagramas iriam confirmar o que, com muita dificuldade de leitura e análise, a tabela de dados revela: o estado de Goiás ainda é marcado por uma distribuição desigual da propriedade no que concerne à relação entre a área e o número de propriedades rurais por categoria de estabelecimento, bem como à sua distribuição regional. Se os mapas permitem visualizar melhor a repartição espacial das propriedades - seja por município, por microrregião ou por mesorregião -, os diagramas mostram com mais contundência a desproporção entre área (ha) e quantidade $(Q)$ dos estabelecimentos rurais, segundo se trata da pequena, média e grande propriedade. O leitor perceberá num piscar de olhos que tanto no detalhe (as microrregiões) como no conjunto (o estado como um todo), a pequena e a grande propriedades são inversamente proporcionais quanto a número (Q) e área (ha) e que entre as duas categorias, a média propriedade tem valores quantitativos e distribuição espacial irregulares. No primeiro caso, a pequena propriedade é fortemente significativa em microrregiões de maior densidade urbana e populacional, enquanto, na outra ponta, a grande propriedade predomina nas microrregiões menos povoadas, ou historicamente marcadas pela prática da pecuária tradicional, como o Noroeste e o Nordeste de Goiás. Algumas exceções, contudo, ainda persistem, pois, no Entorno de Brasília, nos municípios mais afastados da periferia próxima à capital federal, a grande propriedade ainda é marcadamente significativa e ocupa mais da metade da área total das 
propriedades rurais, enquanto que a pequena pouco ultrapassa $20 \%$, apesar de ser marcadamente mais numerosa $-71,3 \%$ do total de propriedades.

Finalmente, diante de tabelas de dados como as aqui apresentadas $n$ soluções gráficas são possíveis, e elas vão desde os diagramas mais simples às distribuições mais complexas, como, por exemplo, os tratamentos gráficos (matrizes, coleção de mapas, diagramas de correlação, de distribuição, diagramas triangulares, cartogramas, anamorfoses etc.) e matemáticos (análise fatorial, por exemplo) da informação.

\section{Considerações finais}

Para encerrar, que conclusões podem ser tiradas dessas contradições? Muitas, sem dúvida, como o caráter ainda concentrador da propriedade - ou melhor, da terra - nas mãos de poucos donos - e a não realização de fato daquilo que para a maioria dos brasileiros deserdados da terra constitui urgência urgentíssima: a reforma agrária, cujo simples enunciado ainda soa como um flagelo para os grandes proprietários rurais. Do ponto de vista puramente técnico-administrativo, uma, porém, deve ser levada seriamente em conta: o cadastramento das propriedades rurais do estado de Goiás revela que, no que concerne ao tamanho das propriedades, as questões relativas à estrutura fundiária parecem trazer os mesmo vícios e contradições relativas à natureza jurídica da propriedade e às relações sociais no campo. Constata-se que, realmente, em muitos municípios, há terra sobrando e que em outros há superposição de propriedades, porque suas áreas ultrapassam as áreas municipais. Sob este último aspecto, convém enfatizar que de um modo geral os proprietários rurais não informam corretamente o que têm, ora omitindo dados, ora superestimando-os. Problemas de ordem cultural ou desinformação? As duas coisas ao mesmo tempo, pois, a história das relações sociais no campo tem mostrado que raramente se exigiu do grande latifundiário a regularização de suas posses. Por isso, escrituras que datam de um século ou mais chegam até o presente com os erros e vícios de origem - imprecisão de áreas e de limites -, o que faz aumentar ou diminuir o tamanho da propriedade e as confusões jurídicas e sociais que disto resultam obrigam todos os proprietários de áreas rurais a realizar o georreferenciamento, o qual consiste na obrigatoriedade da descrição do imóvel rural, em seus limites, características e confrontações, através de memorial descritivo firmado por profissional 
habilitado, com a devida ART (Anotações de Responsabilidade Técnica), "contendo as coordenadas dos vértices definidores dos limites dos imóveis rurais, georreferenciadas ao Sistema Geodésico Brasileiro e com precisão posicional a ser fixada pelo INCRA". Simplificadamente, georreferenciar consiste em "amarrar" as propriedades rurais ao sistema geodésico brasileiro, a fim de melhor localizá-las, discriminá-las, fiscalizá-las e, por fim, regularizá-las. Este procedimento dificulta de certo modo a grilagem de terras, porque, em tese, sem os dados do georreferenciamento, o proprietário fica impedido de lavrar escritura de posse do imóvel e registrá-lo em cartório, receber benefícios fiscais, realizar empréstimos bancários em instituições financeiras públicas, financiar a produção etc. Os prazos não foram inicialmente cumpridos, dando a impressão de que desobrigou-se o proprietário da observância lei, principalmente para aquelas propriedades cujas escrituras permanecem inalteradas há muito tempo. Então, diante de tanta negligência político-administrativa, é normal que as incoerências e as contradições continuem a permear uma das questões mais sensíveis da sociedade brasileira: a propriedade da terra, o acesso a ela e sua regularização fundiária.

Finalmente, os esboços de análise qualitativa e quantitativa aqui mostrados são apenas alguns dos aspectos da questão. Cabe a cada leitor, portanto, segundo sua ótica - ou segundo sua visão particular do assunto - fazer suas próprias análises e interpretações. Não se pode, contudo, perder de vista que em torno de um mesmo problema, não são muitos os conceitos possíveis, mas diante de uma tabela de dados muitas são as soluções gráficas possíveis, tudo depende do que se quer mostrar, e para quem se quer mostrar. 


\section{Anexos}

\begin{tabular}{|c|c|c|c|c|c|c|c|c|c|c|c|c|c|c|c|c|c|}
\hline \multicolumn{18}{|c|}{ IMÓVEIS RURAIS CADASTRADOS NO INCRA POR MUNICÍPIO, MICRORREGIÃO E MESORREGIÃO } \\
\hline \multirow[t]{2}{*}{ Município } & \multirow{2}{*}{\begin{tabular}{|c|} 
Módulo \\
(ha) \\
\end{tabular}} & \multirow[t]{2}{*}{ QT } & \multirow{2}{*}{$\begin{array}{c}\text { Prop } \\
\text { (ha) }\end{array}$} & \multirow{2}{*}{$\begin{array}{l}\text { Mun } \\
\text { (ha) }\end{array}$} & \multirow{2}{*}{$\begin{array}{c}\% / \\
\text { Mun }\end{array}$} & \multicolumn{4}{|c|}{ Pequena Propriedade } & \multicolumn{4}{|c|}{ Média Propriedade } & \multicolumn{4}{|c|}{ Grande Propriedade } \\
\hline & & & & & & Q & $\%$ & (ha) & $\%$ & 0 & $\%$ & (ha) & $\%$ & 0 & $\%$ & (ha) & $\%$ \\
\hline rixás & 60,0 & 1.360 & 427.808 & 466.108 & 91,8 & 889 & 65,4 & 78.190 & 18,3 & 352 & 25,9 & 156.310 & 36,5 & 119 & 8,7 & 193.308 & 45 \\
\hline Mozar & 0,0 & 369 & 166.017 & 3.436 & 95,7 & 180 & 48,8 & 15.31 & 9,2 & 123 & 33,3 & 48.500 & 29,0 & 66 & 17,9 & 102.207 & 61 \\
\hline Mundo & 0,0 & 212 & 220.245 & 665 & 102,6 & 96 & 45,3 & 7.278 & 3,3 & 47 & 22,2 & 26.671 & 12,1 & 69 & 35,5 & 6 & \\
\hline ova & 60,0 & 684 & 74 & 729.880 & 102,3 & 194 & 28,4 & 18.0 & 2,4 & 217 & 31,7 & 118.564 & 15,9 & 273 & 39,9 & 609 & 81, \\
\hline Novo Pla & 70,0 & 98 & 101.522 & 124.264 & 81,6 & 29 & 29,6 & 4.396 & 4,3 & 35 & 35,7 & 21.704 & 21,4 & 34 & 34,7 & 75.422 & \\
\hline J. M. uu Midyudid & (1) & 893 & 542.932 & 0 & 88,4 & 473 & J,0 & 50.150 & , & 289 & 32,4 & 88 & 30,2 & 131 & 14,6 & 329.193 & \\
\hline anur. * & 60,0 & 19 & 55.680 & 5.347 & 48 & 150 &, 4 & 974 & 9,8 & 35 & 17,6 & 83 & 28,9 & 14 & 7,0 & 28.624 & . \\
\hline M. DO ARAGUAIA & 61,4 & 3.815 & 2.260 .715 & 2.438 .138 & 92,7 & 2.011 & 52,7 & 184.380 & 8,1 & 1.098 & 28,8 & 551.420 & 24,4 & 706 & 18,4 & 1.524.915 & 67, \\
\hline
\end{tabular}

\begin{tabular}{|c|c|c|c|c|c|c|c|c|c|c|c|c|c|c|c|c|c|}
\hline \multirow[t]{2}{*}{ Município } & \multirow{2}{*}{\begin{tabular}{c|} 
Módulo \\
(ha)
\end{tabular}} & \multirow[t]{2}{*}{ QT } & \multirow{2}{*}{$\begin{array}{l}\text { Prop } \\
\text { (ha) } \\
\end{array}$} & \multirow{2}{*}{$\begin{array}{l}\text { Mun } \\
\text { (ha) } \\
\end{array}$} & \multirow{2}{*}{$\begin{array}{c}\% / \\
\text { Mun }\end{array}$} & \multicolumn{4}{|c|}{ Pequena Propriedade } & \multicolumn{4}{|c|}{ Média Propriedade } & \multicolumn{4}{|c|}{ Grande Propriedade } \\
\hline & & & & & & 0 & $\%$ & (ha) & $\%$ & 0 & $\%$ & (ha) & $\%$ & 0 & $\%$ & (ha) & $\%$ \\
\hline Araguapaz & 45,0 & 396 & 194.509 & 219.369 & 88,6 & 208 & 52,5 & 15.880 & 8,0 & 103 & 26,0 & 36.989 & 19,0 & 85 & 21,5 & 141.640 & 73,0 \\
\hline Aruană & 50,0 & 239 & 291.060 & 305.030 & 95,4 & 50 & 20,9 & 3.905 & 1,3 & 101 & 42,3 & 43.177 & 14,8 & 88 & 36,8 & 243.978 & 83,9 \\
\hline Britânia & 50,0 & 118 & 162.230 & 146.118 & 111,0 & 35 & 29,7 & 2.242 & 1,4 & 31 & 26,3 & 13.191 & 8,1 & 52 & 44,0 & 146.797 & 90,5 \\
\hline Faina & 45,0 & 1.068 & 191.549 & 194.495 & 98,4 & 770 & 72,1 & 48.883 & 25,5 & 252 & 23,4 & 85.379 & 44,6 & 46 & 4,5 & 57.286 & 29,9 \\
\hline Goiás & 45,0 & 1.921 & 291.258 & 310.801 & 93,7 & 1.520 & 79,1 & 50.039 & 17,2 & 309 & 16,1 & 107.504 & 36,9 & 92 & 4,8 & 133.715 & 45,9 \\
\hline Itapirapuă & 45,0 & 690 & 198.576 & 204.370 & 97,5 & 432 & 62,6 & 28.468 & 14,3 & 193 & 28,0 & 66.661 & 33,6 & 65 & 9,4 & 103.448 & 52,1 \\
\hline Jussara & 45,0 & 941 & 396.289 & 409.246 & 96,8 & 630 & 67,0 & 33.285 & 8,4 & 180 & 19,1 & 62.352 & 15,7 & 131 & 13,9 & 300.651 & 75,9 \\
\hline Matrinchã & 50,0 & 206 & 87.062 & 115.089 & 75,6 & 116 & 56,3 & 8.111 & 9,3 & 56 & 21,2 & 23.461 & 27,0 & 34 & 22,5 & 55.490 & 63,7 \\
\hline Santa Fé de Goiás & 45,0 & 304 & 118.243 & 116.080 & 101,7 & 197 & 64,8 & 12.620 & 10,7 & 69 & 22,7 & 23.548 & 19,9 & 38 & 12,5 & 82.075 & 69,4 \\
\hline RIO VERMELHO & 46,7 & 5.883 & 1.930 .775 & 2.020 .618 & 95,6 & 3.958 & 67,3 & 203.433 & 10,6 & 1.294 & 22,0 & 462.262 & 23,9 & 631 & 10,7 & 1.265 .080 & 65,5 \\
\hline
\end{tabular}

\begin{tabular}{|c|c|c|c|c|c|c|c|c|c|c|c|c|c|c|c|c|c|}
\hline \multirow[t]{2}{*}{ Município } & \multirow{2}{*}{$\begin{array}{c}\text { Módulo } \\
\text { (há) }\end{array}$} & \multirow[t]{2}{*}{ QT } & \multirow{2}{*}{$\begin{array}{c}\text { Prop } \\
\text { (há) }\end{array}$} & \multirow{2}{*}{$\begin{array}{c}\text { Mun } \\
\text { (ha) }\end{array}$} & \multirow{2}{*}{\begin{tabular}{c|}
$\% /$ \\
Mun
\end{tabular}} & \multicolumn{4}{|c|}{ Pequena Propriedade } & \multicolumn{4}{|c|}{ Média Propriedade } & \multicolumn{4}{|c|}{ Grande Propriedade } \\
\hline & & & & & & 0 & $\%$ & (ha) & $\%$ & 0 & $\%$ & (ha) & $\%$ & Q & $\%$ & (ha) & $\%$ \\
\hline Aragarças* & 45,0 & 142 & 45.383 & 71.165 & 63,8 & 92 & 64,8 & 6.138 & 13,5 & 35 & 24,6 & 12.804 & 28,2 & 15 & 10,6 & 26.441 & 70,3 \\
\hline Arenópolis & 50,0 & 462 & 113.176 & 107.459 & 105,3 & 325 & 70,3 & 23.213 & 19,6 & 99 & 21,4 & 37.673 & 33,3 & 38 & 8,3 & 52.290 & 47,1 \\
\hline Baliza & 45,0 & 322 & 190.163 & 178.259 & 106,7 & 167 & 51,7 & 12.290 & 6,5 & 96 & 29,8 & 31.674 & 16,7 & 59 & 18,5 & 146.199 & 76,8 \\
\hline Bom Jardim de Go. & 45,0 & 611 & 183.818 & 185.074 & 99,4 & 407 & 66,6 & 27.925 & 15,2 & 137 & 22,4 & 50.106 & 27,3 & 67 & 11,0 & 105.787 & 57,5 \\
\hline Diorama & 50,0 & 324 & 65.614 & 68.734 & 95,6 & 233 & 71,9 & 17.988 & 27,4 & 74 & 22,8 & 27.582 & 42,1 & 17 & 5,3 & 20.042 & 30,5 \\
\hline M. Claros de Go. & 45,0 & 827 & 305.684 & 289.918 & 105,5 & 524 & 63,4 & 34.156 & 11,2 & 197 & 23,8 & 71.975 & 23,6 & 106 & 12,8 & 199.552 & 65,2 \\
\hline Piranhas & 50,0 & 764 & 241.279 & 204.776 & 117,6 & 497 & 65,1 & 35.829 & 14,8 & 185 & 24,2 & 73.912 & 30,6 & 82 & 10,7 & 131.538 & 54,6 \\
\hline ARAGARÇAS & 47,1 & 3.452 & 1.145.117 & 1.105 .385 & 103,6 & 2.245 & 65,0 & 157.539 & 13,8 & 823 & 23,8 & 305.728 & 26,7 & 384 & 11,2 & 681.850 & 59,5 \\
\hline NOROESTE GOIANO & 52,6 & 13.150 & 5.336 .607 & 5.564.141 & 95,9 & 8.214 & 62,5 & 545.352 & 10,2 & 3.215 & 24,4 & 1.319 .410 & 24,7 & 1.721 & 13,1 & 3.471 .845 & 65,1 \\
\hline
\end{tabular}




\begin{tabular}{|c|c|c|c|c|c|c|c|c|c|c|c|c|c|c|c|c|c|}
\hline \multicolumn{18}{|c|}{ IMÓVEIS RURAIS CADASTRADOS NO INCRA POR MUNICÍPIO, MICRORREGIÃO E MESORREGIÃO } \\
\hline \multirow[t]{2}{*}{ Município } & \multirow{2}{*}{$\begin{array}{c}\text { Módulo } \\
\text { (ha) }\end{array}$} & \multirow[t]{2}{*}{ QT } & \multirow{2}{*}{$\begin{array}{r}\text { Prop } \\
\text { (ha) }\end{array}$} & \multirow{2}{*}{$\begin{array}{r}\text { Mun } \\
\text { (ha) }\end{array}$} & \multirow{2}{*}{\begin{tabular}{c|}
$\% /$ \\
Mun
\end{tabular}} & \multicolumn{4}{|c|}{ Pequena Propriedade } & \multicolumn{4}{|c|}{ Média Propriedade } & \multicolumn{4}{|c|}{ Grande Propriedade } \\
\hline & & & & & & Q & $\%$ & (ha) & $\%$ & Q & $\%$ & (ha) & $\%$ & 0 & $\%$ & (ha) & $\%$ \\
\hline Alto Horizonte* & 60,0 & 79 & 16.823 & 50.376 & 33,4 & 55 & 69,6 & 4.739 & 28,2 & 23 & 29,1 & 11.103 & 66,0 & 1 & 1,3 & 981 & 5,8 \\
\hline Amaralina & 60,0 & 361 & 140.111 & 141.291 & 98,6 & 266 & 95,1 & 22.967 & 16,4 & 60 & 16,6 & 26.797 & 19,8 & 35 & 9,7 & 90.348 & 63,8 \\
\hline Bonópolis* & 60,0 & 201 & 102.367 & 162.848 & 65,6 & 91 & 45,3 & 10.496 & 10,3 & 80 & 39,8 & 3.865 .538 & 37,9 & 30 & 14,9 & 52.766 & 51,8 \\
\hline Campinaçu & 50,0 & 519 & 102.367 & 162.848 & 65,6 & 91 & 45,3 & 10.496 & 10,3 & 80 & 39,8 & 38.655 & 37,9 & 30 & 14,9 & 52.766 & 51,8 \\
\hline Campinorte* & 60,0 & 369 & 62.066 & 106.827 & 58,1 & 314 & 85,1 & 22.276 & 35,9 & 46 & 12,5 & 20.283 & 32,7 & 9 & 2,4 & 19.507 & 31,4 \\
\hline Campos Verdes & 50,0 & 170 & 33.571 & 44.170 & 76,0 & 138 & 81,2 & 9.845 & 29,3 & 24 & 14,1 & 9.456 & 28,2 & 8 & 4,7 & 14.269 & 42,5 \\
\hline Estrela do Norte & 50,0 & 127 & 21.886 & 30.164 & 72,5 & 104 & 81,9 & 6.999 & 32,0 & 16 & 12,5 & 5.154 & 35,3 & 7 & 5,6 & 9.733 & 32,7 \\
\hline Formoso & 50,0 & 387 & 72.309 & 84.420 & 85,7 & 285 & 73,6 & 20.783 & 28,8 & 79 & 20,4 & 26.199 & 36,2 & 23 & 6,0 & 25.327 & 35,0 \\
\hline Mara Rosa* & 60,0 & 1.333 & 281.279 & 170.395 & 165,1 & 1.030 & 77,3 & 88.551 & 31,5 & 255 & 19,1 & 111.047 & 39,5 & 48 & 3,6 & 811.681 & 29,0 \\
\hline Minaçu & 50,0 & 1.324 & 239.686 & 286.072 & 83,1 & 1.093 & 82,5 & 76.130 & 31,7 & 187 & 14,1 & 67.453 & 28,1 & 44 & 3,4 & 96.103 & 40,2 \\
\hline Montv. do Norte* & 50,0 & 243 & 65.971 & 133.299 & 49,6 & 203 & 83,5 & 11.362 & 17,3 & 21 & 8,6 & 8.970 & 13,6 & 19 & 7,9 & 45.640 & 69,1 \\
\hline Mutunópolis & 55,0 & 360 & 91.647 & 86.903 & 105,4 & 244 & 67,8 & 20.071 & 21,4 & 92 & 25,5 & 39.535 & 43,1 & 24 & 6,7 & 32.042 & 35,5 \\
\hline Niquelândia* & 60,0 & 2.560 & 428.504 & 984.317 & 43,5 & 1.837 & 71,7 & 149.678 & 34,9 & 547 & 21,4 & 246.062 & 57,4 & 176 & 6,9 & 32.764 & 7,7 \\
\hline Nova Iguaçu de Go. & 60,0 & 685 & 33.896 & 62.844 & 54,0 & 665 & 97,1 & 23.223 & 68,4 & 18 & 2,6 & 8.596 & 25,4 & 2 & 0,3 & 2.077 & 6,2 \\
\hline Porangatu & 60,0 & 1.308 & 455.560 & 482.049 & 94,5 & 829 & 63,4 & 74.574 & 16,4 & 362 & 27,7 & 174.705 & 38,4 & 117 & 8,9 & 206.281 & 45,2 \\
\hline Santa Tereza de Go. & 50,0 & 164 & 68.489 & 79.455 & 86,2 & 106 & 64,6 & 7.554 & 11,0 & 35 & 21,3 & 14.453 & 21,2 & 23 & 14,1 & 46.482 & 67,8 \\
\hline Sta. Terezinha de Go. & 50,0 & 587 & 98.393 & 120.220 & 81,9 & 467 & 79,6 & 34.979 & 35,5 & 100 & 17,0 & 37.801 & 38,4 & 20 & 3,4 & 25.614 & 26,1 \\
\hline Trombas & 50,0 & 244 & 83.503 & 79.912 & 104,5 & 133 & 54,5 & 12.559 & 15,1 & 84 & 34,4 & 31.818 & 38,1 & 27 & 11,1 & 39.126 & 46,8 \\
\hline Uruaçu & 50,0 & 1.347 & 220.120 & 214.178 & 104,8 & 1.046 & 77,6 & 64.998 & 29,5 & 250 & 18,6 & 92.164 & 41,9 & 51 & 3,8 & 62.969 & 28,6 \\
\hline PORANGATU & 54,5 & 12.368 & 2.657.279 & 3.517 .186 & 75,6 & 9.235 & 74,7 & 691.916 & 26,0 & 2.427 & 19,6 & 1.021 .522 & 38,5 & 706 & 5,7 & 943.841 & 35,5 \\
\hline
\end{tabular}

\begin{tabular}{|c|c|c|c|c|c|c|c|c|c|c|c|c|c|c|c|c|c|}
\hline \multirow[t]{2}{*}{ Município } & \multirow{2}{*}{\begin{tabular}{|c} 
Módulo \\
(ha) \\
\end{tabular}} & \multirow[t]{2}{*}{ QT } & \multirow{2}{*}{$\begin{array}{l}\text { Prop } \\
\text { (ha) }\end{array}$} & \multirow{2}{*}{$\begin{array}{l}\text { Mun } \\
\text { (ha) } \\
\end{array}$} & \multirow{2}{*}{\begin{tabular}{|c|}
$\% /$ \\
Mun
\end{tabular}} & \multicolumn{4}{|c|}{ Pequena Propriedade } & \multicolumn{4}{|c|}{ Média Propriedade } & \multicolumn{4}{|c|}{ Grande Propriedade } \\
\hline & & & & & & Q & $\%$ & (ha) & $\%$ & $Q$ & $\%$ & (ha) & $\%$ & 0 & $\%$ & (ha) & $\%$ \\
\hline Alto Pará́so de Go. & 70,0 & 423 & 188.862 & 259.389 & 72,8 & 264 & 62,4 & 24.091 & 12,7 & 112 & 26,5 & 62.603 & 33,1 & 47 & 11,1 & 102.168 & 54,2 \\
\hline Campos Belos & 80,0 & 184 & 57.341 & 72.406 & 79,1 & 152 & 82,6 & 15.630 & 27,2 & 24 & 13,0 & 14.047 & 24,4 & 8 & 4,4 & 27.664 & 48,4 \\
\hline Cavalcante & 70,0 & 580 & 627.453 & 695.366 & 90,2 & 261 & 45,0 & 30.391 & 4,8 & 160 & 27,6 & 94.989 & 15,1 & 159 & 27,4 & 502.073 & 80,1 \\
\hline Colinas do Sul & 70,0 & 261 & 151.566 & 170.822 & 88,6 & 143 & 54,8 & 17.670 & 11,7 & 80 & 30,6 & 44.481 & 29,4 & 38 & 14,6 & 89.414 & 58,9 \\
\hline Monte Alegre de Go. & 80,0 & 675 & 236.138 & 311.979 & 75,7 & 509 & 75,4 & 47.158 & 20,0 & 117 & 17,3 & 70.765 & 30,0 & 49 & 7,3 & 1.182 .215 & 50,0 \\
\hline Nova Roma* & 70,0 & 120 & 22.087 & 213.595 & 10,3 & 103 & 85,8 & 91.176 & 41,6 & 13 & 0,8 & 5.743 & 26,0 & 4 & 3,4 & 7.167 & 32,4 \\
\hline Săo Joăo D'A Aliança & 70,0 & 589 & 376.131 & 332.732 & 113,0 & 325 & 55,2 & 28.499 & 7,6 & 165 & 28,0 & 97.216 & 28,9 & 99 & 16,8 & 250.416 & 63,5 \\
\hline Teresina de Goiás & 70,0 & 66 & 56.240 & 77.465 & 75,5 & 29 & 43,9 & 3.501 & 6,2 & 21 & 1,8 & 12.837 & 22,8 & 16 & 24,3 & 39.902 & 71,0 \\
\hline CH. DOS VEADEIROS & 72,5 & 2.914 & 1.715 .816 & 213.375 & 80,4 & 1.786 & 61,6 & $\mid 176.116$ & 10,3 & 692 & 23,9 & 402.681 & 23,5 & 420 & 14,5 & 1.137 .019 & 66,2 \\
\hline NORTE GOIANO & 63,5 & 15.282 & 4.373.095 & \begin{tabular}{|l|}
5.650 .937 \\
\end{tabular} & 77,4 & 11.021 & 72,2 & 868.032 & 19,8 & 3.119 & 20,4 & 1.424 .203 & 32,6 & 1.126 & 7,4 & 2.080 .860 & 47,6 \\
\hline
\end{tabular}


B.goiano.geogr, Goiânia, v. 31, n. 2, p. 129-160, jul./dez. 2011 Artigo

\begin{tabular}{|c|c|c|c|c|c|c|c|c|c|c|c|c|c|c|c|c|c|}
\hline IMÓVEIS RUF & CADA & STRAI & DOS NO I & INCRA POF & R MU & NICÍPIC & $\mathrm{O}, \mathrm{MI}$ & ICROR & GI & ME & SORF & REGIÃO & & & & & \\
\hline Município & Módulo & QT & Prop & Mun & $\% /$ & Pequ & uena $\mathrm{F}$ & Propriedac & & & édia $\mathrm{Pr}$ & ropriedade & & & rande $P$ & Propriedade & \\
\hline & (ha) & & (ha) & (ha) & Mun & 0 & $\%$ & (ha) & $\%$ & Q & $\%$ & (ha) & $\%$ & 0 & $\%$ & (ha) & $\%$ \\
\hline Alvorada do Norte & 70,0 & 207 & 108.951 & 125.950 & 86,5 & 123 & 59,4 & 11.698 & 10,7 & 59 & 28,5 & 35.570 & 31,0 & 25 & 12,1 & 63.682 & 58,3 \\
\hline Buritinópolis* & 70,0 & 70 & 4.159 & 26.811 & 15,5 & 67 & 95,7 & 2.689 & 64,8 & 3 & 4,3 & 1.470 & 35,2 & 0 & 0,0 & 0 & 0,0 \\
\hline Damianópolis & 70,0 & 292 & 42.691 & 41.535 & 102,9 & 266 & 91,1 & 16.052 & 37,6 & 20 & 6,8 & 8.172 & 19,1 & 6 & 2,1 & 18.477 & 43,3 \\
\hline Divinópolis de Goiás & 70,0 & 171 & 73.649 & 83.113 & 88,6 & 110 & 64,3 & 11.515 & 17,7 & 74 & 43,3 & 25.875 & 35,1 & 14 & 8,2 & 36.259 & 49,2 \\
\hline Flores de Goiás & 70,0 & 355 & 342.531 & 370.942 & 92,3 & 151 & 45,5 & 18.607 & 5,4 & 40 & 11,3 & 14.296 & 4,2 & 164 & 43,2 & 309.632 & 90,4 \\
\hline Laciara & 70,0 & 286 & 136.743 & 162.528 & 84,1 & 201 & 70,3 & 16.272 & 11,9 & 56 & 19,6 & 31.405 & 23,0 & 29 & 10,1 & 89.066 & 65,1 \\
\hline Mambaí & 70,0 & 402 & 99.120 & 85.956 & 115,2 & 337 & 83,8 & 14.296 & 14,4 & 39 & 9,7 & 23.769 & 24,0 & 26 & 6,5 & 61.055 & 61,6 \\
\hline Posse & 70,0 & 992 & 151.026 & 194.963 & 89,7 & 877 & 88,4 & 45.178 & 29,9 & 90 & 9,1 & 50.248 & 33,2 & 25 & 2,5 & 55.600 & 36,9 \\
\hline São Domingos & 70,0 & 751 & 295.518 & 329.556 & 89,6 & 544 & 72,4 & 43.116 & 14,6 & 142 & 18,9 & 77.968 & 26,4 & 65 & 8,7 & 174.434 & 59,0 \\
\hline Simolândia & 70,0 & 155 & 36.226 & 34.782 & 104,9 & 123 & 79,4 & 7.738 & 21,4 & 23 & 14,8 & 12.476 & 34,5 & 9 & 5,8 & 16.012 & 44,1 \\
\hline Sítio D' Abadia* & 70,0 & 347 & 270.354 & 159.834 & 169,1 & 215 & 62,0 & 16.369 & 6,1 & 81 & 23,3 & 46.499 & 17,2 & 51 & 14,7 & 207.486 & 76,7 \\
\hline VÃO DO PARANÄ & 70,0 & 4.373 & 1.660 .299 & 1.736 .882 & 95,6 & 3.284 & 75,1 & 222.375 & 13,3 & 679 & 15,5 & 358.007 & 21,6 & 437 & 10,0 & 1.079 .917 & 65,1 \\
\hline
\end{tabular}

\begin{tabular}{|c|c|c|c|c|c|c|c|c|c|c|c|c|c|c|c|c|c|}
\hline \multirow[t]{2}{*}{ Município } & \multirow{2}{*}{$\begin{array}{c}\text { Módulo } \\
\text { (ha) }\end{array}$} & \multirow[t]{2}{*}{ QT } & \multirow{2}{*}{$\begin{array}{r}\text { Prop } \\
\text { (ha) }\end{array}$} & \multirow{2}{*}{$\begin{array}{c}\text { Mun } \\
\text { (ha) }\end{array}$} & \multirow{2}{*}{$\begin{array}{c}\% / \\
\text { Mun }\end{array}$} & \multicolumn{4}{|c|}{ Pequena Propriedade } & \multicolumn{4}{|c|}{ Média Propriedade } & \multicolumn{4}{|c|}{ Grande Propriedade } \\
\hline & & & & & & Q & $\%$ & (ha) & $\%$ & 0 & $\%$ & (ha) & $\%$ & 0 & $\%$ & (ha) & $\%$ \\
\hline Abadiânia & 40,0 & 976 & 91.100 & 104.416 & 87,3 & 847 & 86,8 & 39.613 & 43,5 & 111 & 11,4 & 32.189 & 35,3 & 18 & 1,8 & 19.298 & \begin{tabular}{|l|l}
21,8 \\
\end{tabular} \\
\hline Água Fria de Goiás & 35,0 & 515 & 181.659 & 202.941 & 89,6 & 266 & 51,6 & 14.564 & 8,0 & 158 & 30,7 & 47.319 & 28,0 & 91 & 17,7 & 119.776 & \begin{tabular}{|c|c|}
6 & 64,0 \\
\end{tabular} \\
\hline Águas Lindas de $\mathrm{G} 0 .{ }^{*}$ & 40,0 & 50 & 2.777 & 19.120 & 4,6 & 47 & 94,0 & 1.993 & 71,8 & 3 & 6,0 & 784 & 28,2 & 0 & 0,0 & 0 & 0,0 \\
\hline Alexânia & 30,0 & 758 & 63.670 & 84.789 & 75,5 & 623 & 82,2 & 22.641 & 35,4 & 109 & 14,4 & 22.933 & 36,0 & 26 & 3,4 & 18.096 & \begin{tabular}{|l|l}
6,6 \\
\end{tabular} \\
\hline Cabeceiras & 45,0 & 402 & 96.336 & 112.760 & 85,3 & 261 & 64,9 & 15.724 & 16,3 & 104 & 25,9 & 34.694 & 36,0 & 37 & 9,2 & 45.918 & \begin{tabular}{|l|l}
8 & 47,7
\end{tabular} \\
\hline Cidade 0cidental* & 40,0 & 127 & 20.267 & 38.816 & 52,3 & 95 & 74,8 & 4.053 & 20,0 & 21 & 16,5 & 5.558 & 27,4 & 11 & 8,7 & 10.656 & 52,6 \\
\hline Cocalzinho de Goiás & 35,0 & 898 & 129.984 & 178.799 & 72,7 & 712 & 79,3 & 27.668 & 21,3 & 134 & 14,9 & 34.445 & 26,5 & 52 & 5,8 & 67.871 & 52,2 \\
\hline Corumbá de Goiás & 35,0 & 1.038 & 117.380 & 106.246 & 110,5 & 823 & 79,3 & 32.412 & 27,3 & 182 & 17,5 & 46.276 & 39,4 & 33 & 3,2 & 38.693 & \begin{tabular}{|l|l}
33,0 \\
\end{tabular} \\
\hline Cristalina & 40,0 & 1.535 & 572.582 & 616.072 & 92,9 & 809 & 52,7 & 52.641 & 9,2 & 453 & 29,5 & 146.893 & 25,6 & 273 & 17,8 & 373.049 & \begin{tabular}{|l|l}
9 & 65,2
\end{tabular} \\
\hline Formosa & 40,0 & 1.583 & 434.313 & 580.689 & 74,8 & 1.089 & 68,8 & 47.512 & 0,9 & 308 & 19,5 & 102.075 & 23,5 & 186 & 11,7 & 284.727 & \begin{tabular}{|l|l}
765,6 \\
\end{tabular} \\
\hline Luziânia & 40,0 & 2.235 & 360.729 & 396.154 & 91,0 & 1.626 & 72,7 & 80.616 & 22,3 & 488 & 21,8 & 145.590 & 40,4 & 121 & 5,4 & 134.522 & \begin{tabular}{|l}
27,3 \\
\end{tabular} \\
\hline Mimoso de Goiás* & 40,0 & 329 & 94.596 & 138.691 & 68,9 & 202 & 61,4 & 11.463 & 12,1 & 82 & 24,9 & 23.220 & 24,5 & 45 & 13,7 & 59.913 & \begin{tabular}{|l|l}
3 & 63,4
\end{tabular} \\
\hline Novo Gama* & 40,0 & 73 & 1.075 & 19.168 & 5,6 & 71 & 97,3 & 585 & 54,4 & 2 & 2,7 & 491 & 45,6 & 0 & 0,0 & 0 & 0,0 \\
\hline Padre Bernardo & 40,0 & 789 & 292.771 & 313.790 & 93,3 & 444 & 56,3 & 25.270 & 8,6 & 232 & 29,4 & 73.929 & 25,3 & 113 & 14,3 & 193.572 & \begin{tabular}{|l|l}
2 & 66,1 \\
\end{tabular} \\
\hline Pirenópolis & 35,0 & 1.887 & 188.171 & 222.779 & 84,5 & 1.560 & 82,7 & 64.751 & 34,4 & 270 & 14,3 & 67.491 & 35,9 & 57 & 3,0 & 55.930 & 29,7 \\
\hline Planaltina & 35,0 & 691 & 222.457 & 253.911 & 87,6 & 361 & 52,2 & 17.520 & 7,8 & 218 & 31,5 & 66.188 & 29,8 & 112 & 16,3 & 138.750 & 62,4 \\
\hline Sto. Antônio do Desc. & 40,0 & 891 & 79.302 & 93.831 & 84,5 & 763 & 85,6 & 27.080 & 34,1 & 105 & 11,8 & 31.141 & 39,3 & 23 & 2,6 & 21.081 & 26,6 \\
\hline Valparaíso & 40,0 & 25 & 1.557 & 6.011 & 25,9 & 23 & 92,0 & 478 & 30,7 & 2 & 8,0 & 1.079 & 69,3 & 0 & 0,0 & 0 & 0,0 \\
\hline Vila Boa* & 40,0 & 35 & 43.259 & 106.017 & 40,8 & 9 & 25,7 & 883 & 2,0 & 8 & 22,8 & 2.287 & 5,2 & 18 & 51,5 & 40.089 & \begin{tabular}{|l|l}
92,8 \\
9
\end{tabular} \\
\hline Vila Propício & 35,0 & 690 & 191.872 & 218.158 & 87,9 & 440 & 63,8 & 22.243 & 11,6 & 169 & 24,5 & 45.863 & 23,9 & 81 & 11,7 & 123.766 & \begin{tabular}{|l|l}
6 & 64,5 \\
\end{tabular} \\
\hline ENT. DE BRASÍLIA & 38,3 & 15.527 & 3.181 .868 & 3.813.158 & 83,4 & 11.071 & 71,3 & 509.516 & 16,0 & 3.159 & 20,3 & 926.445 & 29,1 & 1.296 & 8,4 & 17.455 .707 & 54,9 \\
\hline LESTE GOIANO & 50,2 & 19.900 & 4.842 .167 & 5.550 .040 & 87,3 & 14.355 & 70,8 & 31.891 & 15,2 & 3.838 & 19,2 & 1.284 .452 & 26,5 & 1.733 & 8,6 & 2.825 .624 & \begin{tabular}{|l}
48,2 \\
58,2
\end{tabular} \\
\hline
\end{tabular}




\begin{tabular}{|c|c|c|c|c|c|c|c|c|c|c|c|c|c|c|c|c|c|}
\hline \multicolumn{18}{|c|}{ IMÓVEIS RURAIS CADASTRADOS NO INCRA POR MUNICÍPIO, MICRORREGIÃO E MESORREGIÃO } \\
\hline \multirow[t]{2}{*}{ Município } & \multirow{2}{*}{$\begin{array}{c}\text { Módulo } \\
\text { (ha) }\end{array}$} & \multirow[t]{2}{*}{ QT } & \multirow{2}{*}{$\begin{array}{l}\text { Prop } \\
\text { (ha) }\end{array}$} & \multirow{2}{*}{$\begin{array}{r}\text { Mun } \\
\text { (ha) }\end{array}$} & \multirow{2}{*}{$\begin{array}{c}\% / \\
\text { Mun }\end{array}$} & \multicolumn{4}{|c|}{ Pequena Propriedade } & \multicolumn{4}{|c|}{ Média Propriedade } & \multicolumn{4}{|c|}{ Grande Propriedade } \\
\hline & & & & & & Q & $\%$ & (ha) & $\%$ & Q & $\%$ & (ha) & $\%$ & Q & $\%$ & (ha) & $\%$ \\
\hline Barro Alto & 30,0 & 472 & 104.179 & 109.324 & 95,3 & 307 & 65,0 & 12.863 & 12,3 & 105 & 22,2 & 25.499 & 24,5 & 60 & 12,6 & 65.835 & 63,2 \\
\hline Carmo do Rio Verde & 20,0 & 669 & 35.174 & 45.592 & 77,1 & 556 & 83,1 & 12.661 & 35,8 & 93 & 13,9 & 12.419 & 35,2 & 20 & 3,0 & 10.094 & 28,0 \\
\hline Ceres & 20,0 & 675 & 22.874 & 21.350 & 104,7 & 613 & 90,8 & 13.218 & 57,7 & 59 & 8,7 & 8.288 & 36,2 & 3 & 0,5 & 1.368 & 6,1 \\
\hline Goianésia & 20,0 & 1.072 & 158.913 & 154.765 & 102,6 & 683 & 63,7 & 22.190 & 14,0 & 289 & 27,0 & 46.372 & 29,2 & 100 & 4,3 & 90.348 & 56,8 \\
\hline Guaraíta & 20,0 & 352 & 19.381 & 20.531 & 94,5 & 295 & 83,8 & 5.360 & 27,8 & 45 & 12,8 & 6.125 & 31,4 & 12 & 3,4 & 7.897 & 40,8 \\
\hline Guarinos* & 50,0 & 336 & 37.094 & 59.587 & 62,2 & 290 & 86,3 & 17.664 & 47,4 & 42 & 12,5 & 15.627 & 42,0 & 4 & 1,2 & 3.823 & 10,6 \\
\hline Hidrolina & 35,0 & 390 & 52.529 & 58.037 & 90,0 & 294 & 75,4 & 15.808 & 30,1 & 79 & 20,3 & 21.181 & 40,3 & 17 & 4,3 & 15.540 & 29,6 \\
\hline Ipiranga de Goiás & 20,0 & 18 & 346 & 24.146 & 1,4 & 18 & 100,0 & 346 & 100,0 & sd & $\mathrm{sd}$ & sd & $\mathrm{sd}$ & $\mathrm{sd}$ & $s d$ & $\mathrm{sd}$ & sd \\
\hline Itapaci & 30,0 & 619 & 108.002 & 95.613 & 113,0 & 395 & 63,9 & 17.550 & 16,3 & 165 & 26,6 & 38.219 & 35,4 & 59 & 9,5 & 52.233 & 48,3 \\
\hline \begin{tabular}{|l} 
Itapuranga \\
\end{tabular} & 20,0 & 2.026 & 115.832 & 127.716 & 90,7 & 1.681 & 83,0 & 39.460 & 34,1 & 290 & 14,3 & 42.118 & 36,4 & 55 & 2,7 & 34.254 & 29,5 \\
\hline Morro Agudo de Go. & 30,0 & 367 & 26.944 & 28.262 & 95,1 & 313 & 85,3 & 12.230 & 45,4 & 45 & 12,3 & 9.643 & 35,7 & 9 & 2,4 & 5.071 & 18,9 \\
\hline Nova América & 30,0 & 225 & 20.055 & 21.202 & 99,3 & 180 & 80,0 & 7.071 & 35,3 & 38 & 16,9 & 7.842 & 38,8 & 7 & 3,1 & 5.143 & 25,9 \\
\hline Nova Glória & 20,0 & 685 & 33.896 & 41.298 & 82,0 & 600 & 87,6 & 14.336 & 42,2 & 67 & 9,8 & 9.399 & 27,8 & 18 & 2,6 & 10.161 & 30,0 \\
\hline Pilar de Goiás & 50,0 & 536 & 92.033 & 90.665 & 102,1 & 427 & \begin{tabular}{|l|}
79,7 \\
\end{tabular} & 27.941 & 30,3 & 90 & 16,8 & 31.770 & 34,6 & 19 & 3,5 & 32.322 & 35,1 \\
\hline Rialma & 20,0 & 192 & 22.053 & 26.896 & 81,8 & 147 & 76,6 & 3.684 & 16,7 & 30 & 15,6 & 4.191 & 19,0 & 15 & 7,8 & 14.178 & 64,3 \\
\hline \begin{tabular}{|l} 
Rianápolis \\
\end{tabular} & 20,0 & 150 & 14.261 & 15.935 & 89,9 & 104 & 69,3 & 2.854 & 20,2 & 34 & 22,7 & 5.223 & 36,4 & 12 & 8,0 & 6.185 & 43,2 \\
\hline Rubiataba & 30,0 & 1.002 & 65.411 & 74.827 & 87,4 & 883 & 88,1 & 30.621 & 46,8 & 100 & 10,0 & 20.166 & 30,9 & 19 & 1,9 & 14.623 & 22,3 \\
\hline Santa Isabel & 20,0 & 434 & 69.760 & 80.681 & 86,5 & 265 & 61,1 & 8.339 & 11,9 & 108 & 24,9 & 16.962 & 24,3 & 61 & 14,0 & 44.459 & 63,8 \\
\hline Sta. Rita do N. Dest. & 30,0 & 295 & 89.404 & 95.604 & 93,5 & 173 & 58,6 & 8.177 & 9,2 & 68 & 23,1 & 16.225 & 18,1 & 54 & 18,3 & 65.002 & 72,7 \\
\hline São Luiz do Norte & 30,0 & 214 & 63.805 & 58.606 & 108,9 & 100 & 46,7 & 5.292 & 8,3 & 72 & 33,6 & 16.764 & 26,3 & 42 & 19,7 & 41.749 & 65,4 \\
\hline São Patrício & 20,0 & 209 & 13.889 & 13.452 & 103,7 & 165 & 78,9 & 3.683 & 26,6 & 38 & 18,2 & 6.232 & 44,5 & 6 & 2,9 & 3.975 & 28,9 \\
\hline Uruana & 20,0 & 683 & 42.514 & 52.213 & 81,4 & 538 & \begin{tabular}{|l|}
78,7 \\
\end{tabular} & 15.217 & 33,4 & 122 & 17,9 & 17.248 & 40,8 & 23 & 3,4 & 10.049 & 23,6 \\
\hline CERES & 26,6 & 11.621 & 1.208 .477 & 1.316 .312 & 83,1 & 9.027 & 77,7 & 296.565 & 24,5 & 1.979 & 17,0 & 377.603 & 31,2 & 615 & 5,3 & 534.309 & 44,3 \\
\hline
\end{tabular}

\begin{tabular}{|c|c|c|c|c|c|c|c|c|c|c|c|c|c|c|c|c|c|}
\hline \multirow[t]{2}{*}{ Município } & \multirow{2}{*}{$\begin{array}{c}\text { Módulo } \\
\text { (ha) }\end{array}$} & \multirow[t]{2}{*}{ QT } & \multirow{2}{*}{$\begin{array}{l}\text { Prop } \\
\text { (ha) }\end{array}$} & \multirow{2}{*}{$\begin{array}{l}\text { Mun } \\
\text { (ha) }\end{array}$} & \multirow{2}{*}{$\begin{array}{l}\% / \\
\text { Mun }\end{array}$} & \multicolumn{4}{|c|}{ Pequena Propriedade } & \multicolumn{4}{|c|}{ Média Propriedade } & \multicolumn{4}{|c|}{ Grande Propriedade } \\
\hline & & & & & & Q & $\%$ & (ha) & $\%$ & Q & $\%$ & (ha) & $\%$ & Q & $\%$ & (ha) & $\%$ \\
\hline Anápolis & 16,0 & 1.477 & 80.285 & 91.838 & 87,4 & 1.160 & 78,5 & 22.753 & 28,3 & 263 & 17,8 & 31.937 & 39,8 & 54 & 3,7 & 25.595 & 31,9 \\
\hline Araçu & 22,0 & 135 & 15.571 & 15.360 & 101,3 & 88 & 65,2 & 2.115 & 13,6 & 34 & 25,2 & 5.592 & 35,9 & 13 & 9,6 & 7.864 & 50,5 \\
\hline Brazabrantes & 20,0 & 155 & 11.993 & 12.355 & 80,5 & 119 & 76,8 & 2.834 & 23,3 & 29 & 18,7 & 4.600 & 38,3 & 7 & 4,5 & 4.558 & 38,4 \\
\hline Campo Limpo de Go.* & 16,0 & 8 & 472 & 15.620 & 3,0 & 6 & 75,0 & 119 & 25,3 & 2 & 25,0 & 353 & 74,7 & 0 & 0,0 & 0 & 0,0 \\
\hline Caturá & 20,0 & 250 & 17.249 & 20.715 & 83,3 & 191 & 76,4 & 5.376 & 31,4 & 49 & 19,6 & 7.496 & 43,6 & 10 & 4,0 & 4.377 & 25,0 \\
\hline Damolândia & 30,0 & 234 & 8.972 & 8.463 & 106,0 & 218 & 93,2 & 5.654 & 63,3 & 16 & 6,8 & 3.318 & 36,7 & 0 & 0,0 & 0 & 0,0 \\
\hline Heitoraí & 20,0 & 245 & 22.461 & 22.966 & 97,8 & 178 & 72,7 & 5.114 & 22,7 & 50 & 20,4 & 8.437 & 37,3 & 17 & 6,9 & 8.910 & 40,0 \\
\hline Inhumas & 24,0 & 958 & 53.580 & 61.335 & 87,4 & 818 & 85,4 & 22.299 & 41,6 & 119 & 12,4 & 19.247 & 35,8 & 21 & 2,2 & 12.034 & 22,4 \\
\hline Itaberaí & 20,0 & 1.581 & 141.356 & 141.117 & 100,2 & 1.187 & 75,1 & 31.921 & 22,6 & 316 & 20,0 & 48.668 & 34,4 & 78 & 4,9 & 60.767 & 43,0 \\
\hline Itaguari & 20,0 & 313 & 15.385 & 15.553 & 98,7 & 273 & 87,3 & 6.835 & 44,2 & 33 & 10,5 & 4.626 & 29,8 & 7 & 2,2 & 3.925 & 26,0 \\
\hline Itaguaru & 20,0 & 332 & 18.334 & 23.994 & 76,3 & 281 & 84,6 & 6.874 & 37,5 & 44 & 13,3 & 6.758 & 37,0 & 7 & 2,1 & 4.703 & 25,5 \\
\hline Itauçu & 26,0 & 418 & 33.475 & 38.368 & 87,2 & 342 & 81,8 & 10.455 & 31,3 & 64 & 15,3 & 12.119 & 36,0 & 12 & 2,9 & 10.901 & 32,7 \\
\hline Jaraguá & 20,0 & 1.934 & 163.689 & 188.894 & 86,7 & 1.430 & 73,9 & 39.214 & 23,9 & 395 & 20,4 & 57.397 & 35,1 & 109 & 5,7 & 67.079 & 41,0 \\
\hline Jesúpolis* & 20,0 & 60 & 4.200 & 12.092 & 34,7 & 53 & 88,4 & 1.381 & 32,9 & 5 & 8,3 & 598 & 14,2 & 2 & 3,3 & 2.221 & 52,9 \\
\hline Nova Veneza* & 22,0 & 219 & 8.358 & 12.338 & 68,3 & 201 & 91,8 & 4.577 & 54,8 & 15 & 6,8 & 2.188 & 26,2 & 3 & 1,4 & 1.593 & 19,0 \\
\hline Ouro Verde de Go. & 20,0 & 316 & 16.924 & 20.968 & 80,5 & 259 & 82,0 & 6.410 & 37,9 & 45 & 14,2 & 5.740 & 33,8 & 12 & 3,8 & 4.774 & 28,3 \\
\hline Petrolina de Goiás & 26,0 & 839 & 43.228 & 54.045 & 80,0 & 743 & 88,6 & 20.405 & 47,2 & 86 & 10,2 & 16.283 & 37,7 & 10 & 1,2 & 6.540 & 15,1 \\
\hline Santa Rosa de Go. & 20,0 & 295 & 14.866 & 17.097 & 87,1 & 255 & 86,5 & 6.394 & 43,0 & 32 & 10,8 & 4.563 & 30,9 & 8 & 2,7 & 3.908 & 26,1 \\
\hline S. Francisco de Go. & 20,0 & 506 & 34.320 & 33.937 & 101,2 & 411 & 81,2 & 11.946 & 34,7 & 78 & 15,4 & 11.477 & 33,5 & 17 & 3,4 & 10.899 & 31,8 \\
\hline Taquaral de Goiás & 20,0 & 331 & 16.936 & 20.139 & 84,1 & 283 & 85,5 & 6.691 & 39,6 & 38 & 11,5 & 5.646 & 33,1 & 10 & 3,0 & 4.599 & 27,3 \\
\hline ANÁPOLIS & 21,1 & 10.606 & 721.745 & 827.174 & 87,2 & 8.496 & 80,1 & 219.437 & 30,4 & $\mid 1.713$ & 16,2 & 257.043 & 35,6 & 397 & 3,7 & 245.265 & 34,0 \\
\hline
\end{tabular}


B.goiano.geogr, Goiânia, v. 31, n. 2, p. 129-160, jul./dez. 2011 Artigo

\begin{tabular}{|c|c|c|c|c|c|c|c|c|c|c|c|c|c|c|c|c|c|}
\hline \multirow{3}{*}{\begin{tabular}{|l} 
IMÓVEIS \\
Município \\
\end{tabular}} & \multirow{3}{*}{\begin{tabular}{|c} 
Módulo \\
(ha)
\end{tabular}} & \multirow{3}{*}{ QT } & \multirow{3}{*}{\begin{tabular}{|l} 
Prop \\
(ha)
\end{tabular}} & \multirow{3}{*}{$\frac{\text { Mun }}{\text { (ha) }}$} & \multirow{3}{*}{\begin{tabular}{|l|}
$\% /$ \\
Mun
\end{tabular}} & MUNI & IIPIO, & IICRO & EGI & $\mathrm{AOE}$ & ES & EGI & & & & & \\
\hline & & & & & & \multicolumn{4}{|c|}{ Pequena Propriedade } & \multicolumn{4}{|c|}{ Média Propriedade } & \multicolumn{4}{|c|}{ Grande Propriedade } \\
\hline & & & & & & Q & $\%$ & (ha) & $\%$ & $Q$ & $\%$ & (ha) & $\%$ & 0 & $\%$ & (ha) & $\%$ \\
\hline Abadia de Goiás & 24,0 & 164 & 11.546 & 14.646 & 78,7 & 137 & 83,6 & 3.970 & 34,4 & 24 & 14,6 & 3.954 & 34,2 & 3 & 1,8 & 3.622 & 31,4 \\
\hline Ap. de Goiânia & 22,0 & 244 & 11.206 & 28.846 & 39,4 & 213 & 87,3 & 4.585 & 40,9 & 25 & 10,2 & 4.112 & 36,7 & 6 & 2,5 & 2.509 & 22,4 \\
\hline Aragoiânia* & 24,0 & 415 & 15.898 & 21.874 & 48,4 & 357 & 86,0 & 4.573 & 28,8 & 53 & 12,8 & 8.953 & 56,3 & 5 & 1,2 & 2.372 & 14,9 \\
\hline Bela Vista de Goiás & 35,0 & 2.173 & 129.152 & 127.662 & 101,2 & 1.985 & 91,3 & 68.948 & 53,3 & 164 & 7,6 & 42.276 & 32,7 & 24 & 1,1 & 17.927 & 14,0 \\
\hline Bonfinópolis* & 16,0 & 89 & 7.574 & 12.226 & 62,3 & 59 & 66,3 & 1.362 & 18,0 & 23 & 25,8 & 2.875 & 37,8 & 7 & 7,9 & 3.337 & 44,2 \\
\hline Caldazinha* & 35,0 & 305 & 11.550 & 31.169 & 37,2 & 292 & 95,8 & 8.422 & 72,9 & 12 & 3,9 & 2.314 & 20,0 & 1 & 0,3 & 814 & 7,1 \\
\hline Goianápolis & 20,0 & 249 & 21.378 & 16.238 & 132,1 & 196 & 78,7 & 4.985 & 23,3 & 38 & 15,3 & 5.410 & 25,2 & 15 & 6,0 & 10.983 & 51,5 \\
\hline Goiânia & 7,0 & 1.043 & 38.982 & 73.949 & 52,7 & 725 & 69,5 & 7.052 & 18,2 & 232 & 22,2 & 12.089 & 31,0 & 86 & 8,2 & 19.841 & 50,8 \\
\hline Goianira & 20,0 & 347 & 23.794 & 20.040 & 119,0 & 257 & 74,1 & 6.432 & 26,9 & 76 & 21,9 & 12.072 & 50,8 & 14 & 4,0 & 5.290 & 22,3 \\
\hline Guapó & 22,0 & 406 & 41.669 & 51.701 & 80,7 & 293 & 72,2 & 8.421 & 20,1 & 83 & 20,4 & 12.758 & 30,7 & 30 & 7,4 & 20.490 & 49,2 \\
\hline Hidrolândia & 35,0 & 1.062 & 81.579 & 94.424 & 86,4 & 898 & 84,6 & 32.712 & 40,1 & 148 & 13,9 & 35.874 & 44,0 & 16 & 1,5 & 12.993 & 15,9 \\
\hline Leop.de Bulhōes & 16,0 & 443 & 35.779 & 49.502 & 72,3 & 288 & 65,0 & 7.104 & 19,8 & 123 & 27,8 & 14.894 & 41,6 & 32 & 7,2 & 13.799 & 38,6 \\
\hline Nerópolis & 20,0 & 284 & 15.596 & 20.422 & 78,0 & 235 & 82,8 & 6.171 & 38,8 & 41 & 14,4 & 5.400 & 33,8 & 8 & 2,8 & 4.385 & 27,4 \\
\hline S. Antônio de Go.* & 20,0 & 36 & 5.357 & 13.280 & 40,6 & 25 & 69,5 & 743 & 13,9 & 7 & 19,4 & 1.150 & 21,5 & 4 & 11,1 & 3.465 & 64,6 \\
\hline Senador Canedo & 7,0 & 382 & 19.417 & 24.475 & 79,2 & 228 & 59,7 & 2.731 & 13,9 & 110 & 28,8 & 6.579 & 34,0 & 44 & 11,5 & 10.107 & 52,1 \\
\hline Terezópolis de Go.* & 20,0 & 36 & 1.895 & 10.698 & 17,7 & 27 & 75,0 & 599 & 31,6 & 9 & 25,0 & 1.296 & 68,4 & 0 & 0,0 & 0 & 0,0 \\
\hline Trindade & 20,0 & 638 & 51.521 & 71.328 & 72,3 & 554 & 86,8 & 22.317 & 43,3 & 75 & 11,8 & 21.704 & 42,1 & 9 & 1,4 & 7.500 & 14,6 \\
\hline GOIÂNIA & 21,3 & 8.315 & 524.266 & 682.480 & 77,0 & 6.679 & 81,4 & 191.128 & 36,5 & 1.243 & 14,9 & 193.704 & 36,9 & 4 & 3,7 & 139.434 & 26,6 \\
\hline
\end{tabular}

\begin{tabular}{|c|c|c|c|c|c|c|c|c|c|c|c|c|c|c|c|c|c|}
\hline \multirow[t]{2}{*}{ Município } & \multirow{2}{*}{$\begin{array}{c}\text { Módulo } \\
\text { (ha) }\end{array}$} & \multirow[t]{2}{*}{ QT } & \multirow{2}{*}{$\begin{array}{l}\text { Prop } \\
\text { (ha) }\end{array}$} & \multirow{2}{*}{$\begin{array}{l}\text { Mun } \\
\text { (ha) }\end{array}$} & \multirow{2}{*}{$\begin{array}{c}\% / \\
\text { Mun }\end{array}$} & \multicolumn{4}{|c|}{ Pequena Propriedade } & \multicolumn{4}{|c|}{ Média Propriedade } & \multicolumn{4}{|c|}{ Grande Propriedade } \\
\hline & & & & & & 0 & $\%$ & (ha) & $\%$ & 0 & $\%$ & (ha) & $\%$ & $Q$ & $\%$ & (ha) & $\%$ \\
\hline Adelândia & 22,0 & 144 & 10.107 & 11.535 & 87,8 & 107 & 74,3 & 2.889 & 28,6 & 32 & 22,2 & 4.623 & 45,7 & 5 & 3,5 & 2.595 & 25,7 \\
\hline Americano do Brasil & 22,0 & 223 & 12.067 & 13.356 & 90,3 & 186 & 83,4 & 5.093 & 42,2 & 34 & 15,3 & 5.590 & 46,3 & 3 & 1,3 & 1.384 & 11,5 \\
\hline Anicuns & 22,0 & 1.319 & 93.793 & 96.161 & 97,5 & 1.074 & 81,4 & 29.007 & 30,9 & 195 & 14,8 & 32.411 & 35,5 & 50 & 3,8 & 323.775 & 34,6 \\
\hline Aurilândia & 28,0 & 393 & 54.771 & 56.515 & 97,0 & 297 & 75,6 & 10.399 & 19,0 & 69 & 17,6 & 15.285 & 27,9 & 27 & 6,8 & 29.087 & 53,1 \\
\hline Avelinópolis & 20,0 & 191 & 16.023 & 16.404 & 97,6 & 140 & 73,3 & 3.277 & 20,6 & 38 & 19,9 & 5.647 & 35,0 & 13 & 6,8 & 7.099 & 44,4 \\
\hline Buriti de Goiás & 22,0 & 183 & 18.172 & 19.929 & 91,5 & 136 & 74,3 & 4.130 & 22,5 & 38 & 20,8 & 6.149 & 33,5 & 9 & 4,9 & 7.893 & 44,0 \\
\hline Firminópolis & 30,0 & 618 & 35.059 & 40.611 & 86,5 & 552 & 89,3 & 18.137 & 51,6 & 57 & 9,2 & 10.822 & 39,8 & 9 & 1,5 & 6.100 & 17,4 \\
\hline Mossâmedes & 22,0 & 722 & 62.836 & 68.445 & 91,8 & 534 & 74,0 & 17.023 & 27,1 & 155 & 21,5 & 25.415 & 40,4 & 33 & 4,5 & 20.398 & 32,5 \\
\hline Nazário & 22,0 & 234 & 30.264 & 3.009 & 101,0 & 167 & 71,4 & 4.362 & 14,5 & 46 & 19,7 & 7.175 & 23,8 & 21 & 8,9 & 18.728 & 61,7 \\
\hline Sanclerlândia & 26,0 & 568 & 44.399 & 49.682 & 89,3 & 462 & 81,3 & 15.161 & 34,2 & 91 & 16,0 & 17.784 & 40,3 & 15 & 2,7 & 11.455 & 25,5 \\
\hline Santa Barbara de Go. & 22,0 & 130 & 12.641 & 13.960 & 90,5 & 95 & 73,1 & 2.544 & 19,8 & 25 & 19,2 & 4.132 & 32,4 & 10 & 7,7 & 5.965 & 47,8 \\
\hline S. Luíz de M. Belos & 30,0 & 1.131 & 66.380 & 82.619 & 80,3 & 994 & 87,9 & 28.708 & 43,2 & 120 & 10,6 & 24.125 & 36,3 & 17 & 1,5 & 13.547 & 20,5 \\
\hline Turvânia & 22,0 & 397 & 49.217 & 47.235 & 104,0 & 276 & 69,5 & 9.008 & 18,3 & 84 & 21,2 & 14.010 & 28,4 & 37 & 9,3 & 26.200 & 53,3 \\
\hline ANICUNS & 23,8 & 6.253 & 505.732 & 546.470 & 92,2 & 5.020 & 80,3 & 149.738 & 29,6 & 984 & 15,7 & 173.168 & 34,2 & 249 & 4,9 & 182.826 & 36,2 \\
\hline
\end{tabular}




\section{IMÓVEIS RURAIS CADASTRADOS NO INCRA POR MUNICÍPIO, MICRORREGIÃO E MESORREGIÃO}

\begin{tabular}{|c|c|c|c|c|c|c|c|c|c|c|c|c|c|c|c|c|c|}
\hline \multirow[t]{2}{*}{ Município } & \multirow{2}{*}{$\begin{array}{c}\text { Módulo } \\
\text { (ha) }\end{array}$} & \multirow[t]{2}{*}{ QT } & \multirow{2}{*}{$\begin{array}{l}\text { Prop } \\
\text { (ha) }\end{array}$} & \multirow{2}{*}{$\begin{array}{l}\text { Mun } \\
\text { (ha) }\end{array}$} & \multirow{2}{*}{$\begin{array}{c}\% / \\
\text { Mun }\end{array}$} & \multicolumn{4}{|c|}{ Pequena Propriedade } & \multicolumn{4}{|c|}{ Média Propriedade } & \multicolumn{4}{|c|}{ Grande Propriedade } \\
\hline & & & & & & Q & $\%$ & (ha) & $\%$ & $Q$ & $\%$ & (ha) & $\%$ & $Q$ & $\%$ & (ha) & $\%$ \\
\hline Amorinópolis & 20,0 & 372 & 38.723 & 40.852 & 94,6 & 260 & 70,0 & 7.988 & 20,6 & 80 & 21,4 & 12.305 & 31,8 & 32 & 8,6 & 18.430 & 47,6 \\
\hline Cachoeira de Go. & 30,0 & 183 & 50.106 & 41.573 & 120,4 & 99 & 54,1 & 5.492 & 11,0 & 54 & 29,5 & 11.813 & 23,6 & 30 & 16,4 & 32.801 & 65,4 \\
\hline Córrego do Ouro & 26,0 & 413 & 46.307 & 46.230 & 100,2 & 295 & 71,4 & 12.699 & 27,4 & 98 & 23,8 & 19.212 & 41,5 & 20 & 4,8 & 14.397 & 31,1 \\
\hline Fazenda Nova & 30,0 & 984 & 118.762 & 128.132 & 92,7 & 779 & 79,2 & 33.732 & 28,4 & 162 & 16,5 & 35.329 & 29,7 & 43 & 4,3 & 49.701 & 41,9 \\
\hline Iporá & 30,0 & 931 & 85.832 & 102.639 & 83,4 & 744 & 79,9 & 30.847 & 35,9 & 161 & 17,3 & 35.205 & 41,0 & 26 & 2,8 & 19.780 & 23,1 \\
\hline Israelândia & 30,0 & 260 & 51.785 & 57.748 & 89,8 & 183 & 70,4 & 7.942 & 15,3 & 51 & 19,6 & 11.675 & 22,6 & 26 & 10,0 & 32.169 & 62,1 \\
\hline Ivolândia & 30,0 & 516 & 125.543 & 126.284 & 99,4 & 276 & 53,5 & 14.397 & 11,5 & 168 & 32,5 & 38.925 & 31,0 & 72 & 14,0 & 72.220 & 57,5 \\
\hline Jaupaci & 22,0 & 196 & 48.426 & 52.720 & 91,8 & 85 & 43,4 & 3.672 & 7,6 & 72 & 36,7 & 12.893 & 26,7 & 39 & 19,9 & 31.861 & 65,7 \\
\hline Moiporá & 30,0 & 243 & 40.538 & 46.062 & 88,0 & 165 & 67,9 & 7.626 & 18,8 & 57 & 23,5 & 13.828 & 34,1 & 21 & 8,6 & 19.085 & 47,1 \\
\hline Novo Brasil & 20,0 & 657 & 67.385 & 64.995 & 103,7 & 463 & 70,5 & 15.209 & 22,6 & 146 & 22,2 & 22.105 & 32,8 & 48 & 7,3 & 30.071 & 44,6 \\
\hline IPORÁ & 26,8 & 4.755 & 673.406 & 707.966 & 95,2 & 3.349 & 70,4 & 139.604 & 20,7 & 1.049 & 22,1 & 213.290 & 31,7 & 357 & 7,5 & 320.512 & 47,6 \\
\hline CENTRO GOIANO & 23,8 & 41.550 & 3.633 .626 & 4.080 .402 & 89,1 & 32.571 & 78,6 & 996.472 & 27,4 & 6.968 & 16,8 & 1.214 .808 & 33,4 & 1.922 & 4,6 & 1.422 .346 & 39,2 \\
\hline
\end{tabular}

\begin{tabular}{|c|c|c|c|c|c|c|c|c|c|c|c|c|c|c|c|c|c|}
\hline \multirow[t]{2}{*}{ Município } & \multirow{2}{*}{$\begin{array}{c}\text { Módulo } \\
\text { (ha) }\end{array}$} & \multirow[t]{2}{*}{ QT } & \multirow{2}{*}{$\begin{array}{l}\text { Prop } \\
\text { (ha) }\end{array}$} & \multirow{2}{*}{$\begin{array}{c}\text { Mun } \\
\text { (ha) }\end{array}$} & \multirow{2}{*}{$\begin{array}{c}\% / \\
\text { Mun }\end{array}$} & \multicolumn{4}{|c|}{ Pequena Propriedade } & \multicolumn{4}{|c|}{ Média Propriedade } & \multicolumn{4}{|c|}{ Grande Propriedade } \\
\hline & & & & & & Q & $\%$ & (ha) & $\%$ & Q & $\%$ & (ha) & $\%$ & 0 & $\%$ & (ha) & $\%$ \\
\hline Ap. do Rio Doce* & 40,0 & 80 & 30.693 & 60.229 & 51,0 & 36 & 45,0 & 2.187 & 7,1 & 27 & 33,8 & 9.091 & 29,6 & 17 & 21,2 & 19.416 & 63,3 \\
\hline Aporé & 40,0 & 445 & 315.949 & 290.034 & 108,9 & 157 & 35,3 & 8.634 & 2,7 & 141 & 31,7 & 47.987 & 15,2 & 147 & 33,0 & 259.328 & 82,1 \\
\hline Caipônia & 60,0 & 1.610 & 851.882 & 865.319 & 98,6 & 836 & 51,9 & 82.843 & 9,7 & 509 & 31,6 & 238.132 & 27,9 & 265 & 16,5 & 531.907 & 62,4 \\
\hline Castelândia* & 30,0 & 39 & 8.908 & 29.743 & 29,9 & 20 & 51,3 & 858 & 9,6 & 12 & 30,8 & 3.267 & 36,7 & 7 & 17,9 & 4.783 & 56,7 \\
\hline Chapadão do Céu & 40,0 & 179 & 193.638 & 235.482 & 82,2 & 88 & 49,2 & 3.796 & 2,0 & 31 & 17,3 & 11.680 & 6,0 & 60 & 33,5 & 178.163 & 92,0 \\
\hline Dorvelândia & 60,0 & 922 & 312.093 & 320.754 & 97,3 & 630 & 68,3 & 37.971 & 12,2 & 190 & 20,6 & 93.813 & 30,1 & 102 & 11,1 & 180.308 & 57,7 \\
\hline Jataí & 40,0 & 2.479 & 812.166 & 717.422 & 113,2 & 1.304 & 52,6 & 77.691 & 9,6 & 829 & 33,4 & 264.381 & 32,5 & 346 & 14,0 & 470.094 & 57,9 \\
\hline Maurilândia & 22,0 & 234 & 34.906 & 39.379 & 87,7 & 153 & 65,4 & 6.030 & 17,2 & 52 & 22,2 & 8.821 & 25,2 & 29 & 12,4 & 20.055 & 57,6 \\
\hline Mineiros & 60,0 & 1.817 & 929.292 & 889.630 & 104,5 & 962 & 52,9 & 5.413 & 10,3 & 611 & 33,6 & 293.295 & 31,6 & 244 & 13,5 & 540.584 & 58,1 \\
\hline Montividiu & 30,0 & 687 & 215.071 & 187.461 & 114,7 & 331 & 48,2 & 16.259 & 7,6 & 208 & 30,3 & 49.658 & 23,1 & 148 & 21,5 & 149.153 & 69,0 \\
\hline Palestina de Goiás & 60,0 & 415 & 116.448 & 132.068 & 126,0 & 297 & 71,6 & 24.000 & 20,6 & 94 & 22,6 & 41.436 & 35,6 & 24 & 5,8 & 51.011 & 43,8 \\
\hline Perolândia & 40,0 & 254 & 90.477 & 102.962 & 87,9 & 128 & 50,4 & 7.669 & 8,5 & 84 & 33,1 & 29.150 & 32,2 & 42 & 16,5 & 53.659 & 59,3 \\
\hline Portelândis & 60,0 & 270 & 45.558 & 55.064 & 82,7 & 221 & 81,9 & 18.213 & 39,9 & 42 & 15,6 & 17.128 & 37,7 & 7 & 2,5 & 10.218 & 22,4 \\
\hline Rio Verde & 30,0 & 3.723 & 886.088 & 838.830 & 105,6 & 2.108 & 56,6 & 101.770 & 11,5 & 1.107 & 29,7 & 262.082 & 29,6 & 508 & 13,7 & 522.235 & 58,9 \\
\hline Santa Helena de Go. & 20,0 & 853 & 119.574 & 112.786 & 106,0 & 521 & 61,1 & 17.838 & 14,9 & 240 & 28,1 & 37.560 & 31,4 & 92 & 10,8 & 64.176 & 53,7 \\
\hline Sta. Rita do Araguaia & 60,0 & 260 & 138.263 & 136.176 & 101,5 & 103 & 39,6 & 10.360 & 7,5 & 119 & 45,8 & 52.712 & 38,1 & 38 & 14,6 & 75.190 & 54,4 \\
\hline S. Antônio da Barra* & 30,0 & 112 & 24.447 & 45.160 & 54,1 & 69 & 61,6 & 3.583 & 14,7 & 27 & 24,1 & 6.254 & 25,8 & 16 & 14,3 & 14.610 & 59,6 \\
\hline Serranópolis & 40,0 & 879 & 535.843 & 552.653 & 97,0 & 327 & 37,2 & 22.873 & 4,3 & 306 & 34,8 & 101.933 & 19,0 & 246 & 28,0 & 411.037 & 76,7 \\
\hline SUDOESTE GOIANO & 42,3 & 15.258 & 5.661 .895 & 5.611 .152 & 100,9 & 8.211 & 54,3 & 537.988 & 9,5 & 4.629 & 30,3 & 1.567 .980 & 27,7 & 2.338 & 15,4 & 3.555 .927 & 62,8 \\
\hline
\end{tabular}


B.goiano.geogr, Goiânia, v. 31, n. 2, p. 129-160, jul./dez. 2011

Artigo

\begin{tabular}{|c|c|c|c|c|c|c|c|c|c|c|c|c|c|c|c|c|c|}
\hline \multicolumn{18}{|c|}{ IMÓVEIS RURAIS CADASTRADOS NO INCRA POR MUNICÍPIO, MICRORREGIÃO E MESORREGIÃO } \\
\hline \multirow[t]{2}{*}{ Município } & \multirow{2}{*}{$\begin{array}{c}\text { Módulo } \\
\text { (ha) }\end{array}$} & \multirow[t]{2}{*}{ QT } & \multirow{2}{*}{$\begin{array}{l}\text { Prop } \\
\text { (ha) }\end{array}$} & \multirow{2}{*}{$\begin{array}{r}\text { Mun } \\
\text { (ha) }\end{array}$} & \multirow{2}{*}{$\begin{array}{c}\% / \\
\text { Mun }\end{array}$} & \multicolumn{4}{|c|}{ Pequena Propriedade } & \multicolumn{4}{|c|}{ Média Propriedade } & \multicolumn{4}{|c|}{ Grande Propriedade } \\
\hline & & & & & & 0 & $\%$ & (ha) & $\%$ & Q & $\%$ & (ha) & $\%$ & 0 & $\%$ & (ha) & $\%$ \\
\hline Tacho & 24,0 & 879 & 3.635 & 165.434 & 98,9 & 507 & 57,7 & 21.261 & 13,0 & 249 & 28,3 & 46.609 & 28,5 & 123 & 14,0 & 95.765 & 58, \\
\hline ¿açu & 35,0 & 813 & 34.107 & 225.110 & 104,0 & 501 & 61,6 & 23.985 & 10,2 & 198 & 24,3 & 57.467 & 24,5 & 114 & 14,1 & 152.656 & 65, \\
\hline Gouve & 30 & 293 & 1337 & 83.077 & 89,5 & 164 & 56,0 & 7.644 & 10,2 & 77 & 26,3 & 19.220 & 25 & 52 & 17,7 & 47.473 & 64 \\
\hline Itajá & 30 & 328 & 206.038 & 209.139 & 98,5 & 86 & 26 & 5.65 & 28 & 122 & 37,2 & 31.808 & 15 & 120 & 36,7 & 168.574 & 81 \\
\hline Itarumă & 35,0 & 639 & 331.735 & 343.362 & 96,7 & 2.141 & 33,5 & 13.448 & 4,0 & 220 & 34,4 & 66.138 & 20,0 & 205 & 32,1 & 252.149 & 76, \\
\hline Lagoa Santa & 30,0 & sd & $s d$ & 45.887 & $?$ & sd & $s d$ & sd & $s d$ & sd & $s d$ & sd & sd & sd & $s d$ & sd & $s d$ \\
\hline Paranaiguara & 30,0 & 278 & 112.141 & 115.379 & 97,2 & 117 & 42,1 & 5.534 & 4,9 & 102 & 36,7 & 24.334 & 21,7 & 59 & 21,2 & 82.272 & 73 \\
\hline Quirinópolis & 30,0 & 2.027 & 396.967 & 378.017 & 105,0 & 1.348 & 66,5 & 64.096 & 16,1 & 482 & 23,8 & 110.454 & 27,9 & 197 & 9,7 & 222.417 & 56 \\
\hline Săo Simāo & 35,0 & 86 & 35.849 & 41.406 & 82,9 & 36 & 41,9 & 1.550 & 4,2 & 29 & 33,7 & 9.873 & 27,6 & 21 & 24,4 & 24.426 & 68, \\
\hline QUIRINÓPOLIS & 31,0 & 5.343 & 1.554 .809 & 1.606 .811 & 99,6 & 2.973 & 55,6 & 143.174 & 9,2 & 1.479 & 27,7 & 365.903 & 23,5 & 891 & 16,7 & 1.045 .732 & 67,3 \\
\hline
\end{tabular}

\begin{tabular}{|c|c|c|c|c|c|c|c|c|c|c|c|c|c|c|c|c|c|}
\hline \multirow[t]{2}{*}{ Município } & \multirow{2}{*}{\begin{tabular}{|c|} 
Módulo \\
(há) \\
\end{tabular}} & \multirow[t]{2}{*}{ QT } & \multirow{2}{*}{$\begin{array}{c}\text { Prop } \\
\text { (há) }\end{array}$} & \multirow{2}{*}{$\begin{array}{c}\text { Mun } \\
\text { (ha) }\end{array}$} & \multirow{2}{*}{\begin{tabular}{|c|}
$\% /$ \\
Mun
\end{tabular}} & \multicolumn{4}{|c|}{ Pequena Propriedade } & \multicolumn{4}{|c|}{ Média Propriedade } & \multicolumn{4}{|c|}{ Grande Propriedade } \\
\hline & & & & & & 0 & $\%$ & (ha) & $\%$ & 0 & $\%$ & (ha) & $\%$ & 0 & $\%$ & (ha) & $\%$ \\
\hline Acreúna & 30,0 & 475 & 167.984 & 156.599 & 107,3 & 239 & 50,3 & 12.172 & 7,2 & 135 & 28,4 & 33.058 & 19,7 & 101 & 21,3 & 122.754 & 73,1 \\
\hline Campestre de Go.* & 20,0 & 154 & 17.791 & 27.382 & 64,8 & 110 & 71,4 & 3.709 & 20,8 & 38 & 24,7 & 6.274 & 35,4 & 6 & 3,9 & 7.809 & 43,8 \\
\hline Cezarina & 22,0 & 466 & 38.966 & 41.581 & 93,7 & 346 & 74,2 & 9.500 & 24,2 & 102 & 21,9 & 15.633 & 40,0 & 18 & 3,9 & 13.834 & 35,6 \\
\hline Edealina & 30,0 & 522 & 67.271 & 60.635 & 111,4 & 367 & 70,3 & 15.779 & 23,5 & 116 & 22,2 & 25.725 & 38,2 & 39 & 7,5 & 25.766 & 38,3 \\
\hline Edéia & 30,0 & 1.563 & 153.509 & 146.152 & 105,0 & 1.292 & 82,7 & 15.071 & 9,8 & 187 & 12,0 & 44.615 & 29,1 & 84 & 5,3 & 98.823 & 61,1 \\
\hline Indiara & 30,0 & 542 & 88.738 & 95.647 & 92,8 & 357 & 65,9 & 15.905 & 17,9 & 142 & 26,2 & 33.154 & 37,3 & 43 & 7,9 & 39.680 & 44,8 \\
\hline Jandaia & 30,0 & 642 & 81.140 & 86.410 & 93,9 & 476 & 74,1 & 19.131 & 23,6 & 138 & 21,5 & 30.036 & 37,0 & 28 & 4,4 & 31.973 & 39,4 \\
\hline Palmeiras de Goiás & 22,0 & 1.308 & 151.050 & 153.968 & 98,1 & 915 & 70,0 & 28.226 & 12,1 & 306 & 23,4 & 49.399 & 21,3 & 87 & 6,6 & 73.425 & 31,6 \\
\hline Palminópolis & 30,0 & 420 & 41.782 & 38.769 & 107,7 & 338 & 80,5 & 15.018 & 35,9 & 68 & 16,2 & 13.958 & 33,5 & 14 & 3,3 & 12.806 & 30,6 \\
\hline Paraúna & 30,0 & 896 & 395.331 & 378.122 & 104,5 & 429 & 47,8 & 27.592 & 7,0 & 219 & 24,5 & 62.392 & 15,8 & 248 & 27,7 & 305.347 & 77,2 \\
\hline S. João da Paraúna & 30,0 & 175 & 23.106 & 30.536 & 75,7 & 134 & 76,6 & 6.352 & 27,7 & 33 & 18,8 & 7.443 & 32,0 & 8 & 4,6 & 9.311 & 40,3 \\
\hline Turvelândia & 30,0 & 297 & 95.834 & 93.426 & 102,6 & 142 & 47,8 & 7.729 & 8,0 & 97 & 32,6 & 24.059 & 25,2 & 58 & 19,6 & 64.046 & 66,8 \\
\hline Varjäo* & 35,0 & 357 & 22.795 & 51.910 & 43,9 & 261 & 73,1 & 11.744 & 51,6 & 86 & 24,1 & 2.201 & 9,0 & 10 & 2,8 & 8.851 & 38,8 \\
\hline RIO DOS BOIS & 26,1 & 7.817 & 1.344 .400 & 1.360 .867 & 98,9 & 5.406 & 56,2 & \begin{tabular}{|l|}
187.028 \\
\end{tabular} & 13,9 & 1.667 & 21,3 & 347.947 & 25,9 & 744 & 9,5 & 809.425 & 60,2 \\
\hline
\end{tabular}




\begin{tabular}{|c|c|c|c|c|c|c|c|c|c|c|c|c|c|c|c|c|c|}
\hline & & & & & & & & & & & & & & & & & \\
\hline Município & & QT & rop & un & $\% /$ & Peq & quena & Propri & & & éd & ade & & & rande & edac & \\
\hline & & & hal & (ha) & Mun & Q & $\%$ & (ha) & $\%$ & 0 & $\%$ & (ha) & $\%$ & Q & $\%$ & (ha) & $\%$ \\
\hline ua L L & 45,0 & 227 & 36.127 & 45.286 & 79,8 & 187 & 82,4 & 646 & 29,5 & 28 & 12,3 & 8.192 & 22,7 & 12 & 5,3 & 17.290 & 47,8 \\
\hline Aloândia & 35,0 & 184 & 10.071 & 10.216 & 100,5 & 168 & 91,3 & 6.120 & 60,8 & 14 & 7,6 & 2.819 & 28,0 & 2 & 1,1 & 1.132 & 11,2 \\
\hline m Jes & 22,0 & 664 & 178.889 & 140.522 & 127,3 & 283 & 42,5 & 11.552 & 6,5 & 242 & 36,4 & 43.063 & 24,1 & 139 & 20,1 & 124.270 & 69,4 \\
\hline ritit Alegre & 40,0 & 473 & 77.204 & 89.739 & 86,0 & 319 & 67,4 & 18.639 & 24,1 & 138 & 29,2 & 38.992 & 50,5 & 16 & 3,4 & 19.574 & 25,4 \\
\hline Cachoe & 24,0 & 323 & 47.080 & 52.113 & 90,3 & 202 & 62,5 & 7.341 & 15,5 & 87 & 26,9 & 16.655 & 35,5 & 34 & 10,6 & 23.084 & 49,0 \\
\hline aldas I & 45,0 & 918 & 4534 & 158.952 & 90,9 & 702 & 76,5 & 8.347 & 26,5 & 191 & 20,8 & 3.032 & 3,6 & 25 & 2,7 & 43.156 & 29,9 \\
\hline Cromínia & 35,0 & 270 & 32.712 & 36.992 & 88,4 & 212 & 78,5 & 9.870 & 30,3 & 50 & 18,5 & 12.811 & 39,1 & 8 & 3,0 & 10.032 & 30,6 \\
\hline oiatuba & 30,0 & 1.009 & 216.785 & 247.511 & 87,6 & 581 & 57,6 & 27.091 & 12,5 & 307 & 30,4 & 3.417 & 33,9 & 121 & 12,0 & 116.278 & 53,6 \\
\hline rcio & 24,0 & 125 & 586 & 68.840 & 29,9 & 64 & 51,2 & 2.726 & 132 & 49 & 39,2 & 8.485 & 41,2 & 12 & 9,6 & 9.375 & 5,6 \\
\hline Itubiara & 24,0 & 1.776 & 245.226 & 246.128 & 99,6 & 1.101 & 62,0 & 46.001 & 18,8 & 537 & 30,2 & 99.289 & 40,5 & 138 & 7,8 & 99.936 & 40,7 \\
\hline Joviânia & 2 & 326 & 488 & 488 & 122,0 & 197 & 60,4 & 508 & , & 103 & 31,0 & 1.839 & 9,3 & 26 & 8,0 & 26.141 & 47,2 \\
\hline Mairipotaba & 35,0 & 291 & 48.417 & .098 & 105,0 & 207 & 7 & .956 & 24,6 & 69 & 23 & 19.075 & 39,5 & 15 & 5,2 & 17.386 & 350 \\
\hline Marzagão & 45,0 & 116 & 21.434 & 22.809 & 93,9 & 90 & 77,6 & 5.755 & 26,6 & 19 & 16,4 & 5.610 & 26,2 & 7 & 6,0 & 10.069 & 47,2 \\
\hline Morrinhos & 40,0 & 2. & 0.351 & 4.619 & 95,0 & 1.139 & 7 & .170 & 33,7 & 392 & 17,9 & 18 & 0 & 57 & 2,6 & 5.543 & 4,3 \\
\hline namá & 20,0 & 346 & 41.697 & 43.376 & 96,1 & 191 & 55,2 & 7.115 & 17,0 & 122 & 35,3 & 18.779 & 45,1 & 33 & 9,5 & 15.803 & 37,9 \\
\hline Piracanjuba & 30,0 & 2.058 & 219.430 & 240.511 & 91,2 & 1.556 & 75,6 & 63.342 & 28,8 & 420 & 20,4 & 92.991 & 42,4 & 82 & 4,0 & 63.098 & 28,8 \\
\hline ontal & 35,0 & 947 & 129.366 & 19 & 90 & 691 & 73 & 36.074 & 27,9 & 211 & 22,3 & 76 & 42,2 & 45 & 4,7 & 38.715 & 29,9 \\
\hline orteirão & 3 & 7 & 44.081 & 60.392 & 73,0 & 19 & 25,7 & 830 & 1,9 & 23 & 31 & 7.018 & 15,9 & 32 & 43,3 & 36.234 & 82,2 \\
\hline Professor Jamil* & 3 & 103 & 12.733 & 34.746 & 36,6 & 80 & 77,7 & 2.687 & 21,3 & 15 & 14,6 & 2.805 & 22,0 & 8 & 7,7 & 7.241 & 56,7 \\
\hline $0 \mathrm{Qu}$ & 45,0 & 247 & 年808 & 26.674 & 85,8 & 193 & 85,0 & 11.110 & 48,0 & 31 & 年, & 8.881 & 38,8 & 3 & 1,3 & 2.869 & 12,6 \\
\hline . & 35,0 & 223 & 580 & 73.7 & 8 & 109 & 48,9 & 30 & 1,8 & 86 & 38,6 & 24.915 &, 8 & 28 & 12,5 & 27.634 & 46,4 \\
\hline MEIA PONTE & 33,1 & 12.868 & 1.934 .641 & 2.117 .556 & 91,4 & 8.891 & 69,1 & 422.919 & 21,9 & 3.134 & 24,4 & 736.862 & 38,1 & 843 & 6,5 & 774.860 & 40,0 \\
\hline
\end{tabular}

\begin{tabular}{|c|c|c|c|c|c|c|c|c|c|c|c|c|c|c|c|c|c|}
\hline \multirow[t]{2}{*}{ Município } & \multirow{2}{*}{$\begin{array}{c}\text { Módulo } \\
\text { (ha) }\end{array}$} & \multirow[t]{2}{*}{ QT } & \multirow{2}{*}{$\begin{array}{l}\text { Prop } \\
\text { (ha) }\end{array}$} & \multirow{2}{*}{$\begin{array}{c}\text { Mun } \\
\text { (ha) }\end{array}$} & \multirow{2}{*}{\begin{tabular}{c|}
$\% /$ \\
Mun
\end{tabular}} & \multicolumn{4}{|c|}{ Pequena Propriedade } & \multicolumn{4}{|c|}{ Média Propriedade } & \multicolumn{4}{|c|}{ Grande Propriedade } \\
\hline & & & & & & 0 & $\%$ & (ha) & $\%$ & 0 & $\%$ & (ha) & $\%$ & 0 & $\%$ & (ha) & $\%$ \\
\hline Cristianópolis & 35,0 & 218 & 19.652 & 22.536 & 87,2 & 181 & 83,0 & 8.352 & 42,5 & 33 & 15,1 & 7.876 & 40,1 & 4 & 1,9 & 3.424 & 17,4 \\
\hline Gameleira de Goiás* & 30,0 & 40 & 5.516 & 59.532 & 7,6 & 28 & 70,0 & 1.342 & 24,3 & 11 & 27,5 & 2.564 & 46,5 & 1 & 2,5 & 1.611 & 29,2 \\
\hline Orizona & 35,0 & 2.138 & 185.896 & 197.287 & 94,2 & 1.790 & 83,7 & 80.828 & 43,5 & 313 & 14,6 & 74.832 & 40,2 & 35 & 1,7 & 30.236 & 16,3 \\
\hline Palmelo* & 30,0 & 35 & 2.825 & 5.900 & 39,4 & 30 & 85,7 & 1.238 & 43,8 & 5 & 14,2 & 1.587 & 56,2 & 0 & 0,0 & 0 & 0,0 \\
\hline Pires do Rio & 35,0 & 662 & 86.100 & 107.337 & 80,2 & 483 & 73,0 & 24.061 & 27,9 & 153 & 23,1 & 39.356 & 45,8 & 26 & 3,9 & 22.683 & 26,3 \\
\hline Santa Cruz de Goiás & 35,0 & 695 & 101.423 & 110.892 & 91,5 & 489 & 70,3 & 26.055 & 25,7 & 171 & 24,6 & 43.304 & 42,7 & 35 & 5,1 & 32.064 & 31,6 \\
\hline S.M.do P. Quatro & 30,0 & 715 & 53.434 & 53.778 & 99,3 & 596 & 83,4 & 21.048 & 39,3 & 104 & 14,5 & 21.466 & 40,3 & 15 & 2,1 & 10.920 & 20,4 \\
\hline Silvânia & 30,0 & 2.118 & 254.149 & 226.477 & 112,2 & 1.575 & 74,4 & 63.843 & 25,1 & 426 & 20,1 & 96.842 & 38,1 & 117 & 5,5 & 93.464 & 36,8 \\
\hline Urutaí & 30,0 & 392 & 53.702 & 62.672 & 85,7 & 273 & 69,6 & 11.974 & 22,3 & 99 & 25,3 & 21.033 & 39,1 & 20 & 5,1 & 20.694 & 38,6 \\
\hline Vianópolis & 40,0 & 919 & 94.522 & 95.428 & 99,0 & 754 & 82,0 & 37.661 & 39,9 & 148 & 16,1 & 42.505 & 45,0 & 17 & 1,9 & 14.357 & 15,1 \\
\hline PIRES DO RIO & 33,0 & 7.932 & 857.239 & 941.839 & 91,0 & 6.199 & 78,2 & 276.402 & 32,2 & 1.463 & 18,4 & 351.385 & 41,0 & 270 & 3,4 & 229.452 & 26,8 \\
\hline
\end{tabular}




\begin{tabular}{|c|c|c|c|c|c|c|c|c|c|c|c|c|c|c|c|c|c|}
\hline \multirow{3}{*}{\begin{tabular}{|l|} 
IMÓVEIS R \\
Município \\
\end{tabular}} & \multirow{3}{*}{$\begin{array}{c}\text { Módulo } \\
\text { (ha) }\end{array}$} & \multirow{3}{*}{ QT } & \multirow{3}{*}{$\begin{array}{l}\text { Prop } \\
\text { (ha) }\end{array}$} & \multirow{3}{*}{$\begin{array}{l}\text { Mun } \\
\text { (ha) }\end{array}$} & \multirow{3}{*}{\begin{tabular}{c|}
$\% /$ \\
Mun
\end{tabular}} & MUNICÍ & ÍPIO, & MICRORR & REGIÁ & AिOEM & IESO & RREGIÃO & & & & & \\
\hline & & & & & & \multicolumn{4}{|c|}{ Pequena Propriedade } & \multicolumn{4}{|c|}{ Média Propriedade } & \multicolumn{4}{|c|}{ Grande Propriedade } \\
\hline & & & & & & 0 & $\%$ & (ha) & $\%$ & 0 & $\%$ & (ha) & $\%$ & 0 & $\%$ & (ha) & $\%$ \\
\hline Anhaguera* & 45,0 & 16 & 3.077 & 5.664 & 54,3 & 12 & 75,0 & 1.110 & 36,0 & 3 & 18,8 & 854 & 27,8 & 1 & 6,2 & 1.112 & 36,2 \\
\hline $\begin{array}{l}\text { Campo Alegre } \\
\text { de Goiás }\end{array}$ & 28,0 & 663 & 208.826 & 246.301 & 84,8 & 281 & 42,4 & 15.199 & 7,3 & 261 & 39,4 & 59.046 & 28,3 & 121 & 18,2 & 134.581 & 64,4 \\
\hline Catalāo & 40,0 & 2.302 & 357.507 & 377.765 & 94,6 & 1.787 & 77,6 & 91.977 & 25,7 & 404 & 17,5 & 122.141 & 34,2 & 111 & 4,9 & 143.390 & 40,1 \\
\hline Corumbaíba & 45,0 & 795 & 152.900 & 188.171 & 80,8 & 555 & 69,8 & 38.795 & 25,4 & 201 & 25,3 & 68.816 & 45,0 & 39 & 4,9 & 45.290 & 29,6 \\
\hline Cumari* & 45,0 & 337 & 39.816 & 57.988 & 68,7 & 270 & 80,1 & 15.395 & 38,7 & 60 & 17,8 & 18.910 & 47,5 & 7 & 2,1 & 5.512 & 13,8 \\
\hline Divinópolis & 30,0 & 375 & 47.552 & 52.004 & 91,4 & 265 & 70,7 & 12.944 & 27,2 & 93 & 24,8 & 20.178 & 42,4 & 17 & 4,5 & 14.430 & 30,1 \\
\hline Goiandira & 35,0 & 458 & 50.538 & 56.071 & 90,1 & 359 & 78,4 & 20.129 & 39,8 & 91 & 19,9 & 22.431 & 44,4 & 8 & 1,7 & 7.978 & 15,8 \\
\hline Ipameri & 40,0 & 1.390 & 439.413 & 436.869 & 100,6 & 717 & 51,6 & 47.014 & 10,7 & 491 & 35,3 & 155.700 & 35,4 & 182 & 13,1 & 236.699 & 53,9 \\
\hline Nova Aurora & 45,0 & 208 & 27.337 & 30.266 & 90,4 & 174 & 83,7 & 11.304 & 41,4 & 26 & 12,5 & 7.287 & 26,7 & 8 & 3,8 & 8.746 & 31,9 \\
\hline Ouridor & 40,0 & 478 & 32.745 & 41.379 & 79,1 & 438 & 91,6 & 19.346 & 59,0 & 36 & 7,5 & 9.294 & 28,4 & 4 & 0,9 & 4.106 & 12,6 \\
\hline Três Ranchos & 40,0 & 354 & 18.561 & 28.206 & 65,8 & 336 & 94,9 & 12.577 & 67,8 & 17 & 4,8 & 5.132 & 27,6 & 1 & 0,3 & 852 & 4,6 \\
\hline CATALÄ0 & 39,4 & 7.376 & 1.378.275 & 1.520 .684 & 90,6 & 5.194 & 70,4 & 285.790 & 20,7 & 1.683 & 22,8 & 489.789 & 35,5 & 499 & 6,8 & 602.696 & 43,8 \\
\hline SUL GOIANO & 34,9 & 56.594 & 12.731 .259 & 13.158 .909 & 96,8 & 36.874 & 65,3 & 1.853 .301 & 14,6 & 14.055 & 4,8 & 3.859 .866 & 30,3 & 5.585 & 9,9 & 7.018 .092 & 55,1 \\
\hline GOIÁS & 37,9 & 146.476 & 30.916 .554 & 34.004 .429 & 90,8 & 103.035 & 70,5 & \begin{tabular}{|l|}
4.995 .048 \\
\end{tabular} & 16,1 & 31.195 & 21,3 & \begin{tabular}{|l|}
9.102 .739 \\
\end{tabular} & 29,4 & 12.087 & 8,2 & 16.818 .767 & 54,4 \\
\hline
\end{tabular}

Fonte: Instituto Nacional de Colonizaçāo e Reforma Agrária-INCRA. Elaboraçāo: SEPLAN-Go/Gerência de Estatísticas Socioeconômicas- 2003. in: Anuário Estatistico do Estado de Goidús, 2005 (www. seplan.go.gov.br/sepin. pub/anuario/2005)

\section{CONVENÇÕ̃ES ADOTADAS NESTA TABELA}

Módulo - Módulo fiscal em cada município, microrregiăo e mesorregiăo expresso em hectares (ha)

QT - Quantidade total de propriedades em cada município, microrregião e mesorregião

Mun - Área do município expressa em hectares (ha)

\% / - Proporçăo da área das propriedades com relaçăo à área do município

Q- Quantidade de propriedades segundo o tamanho (se pequena, média ou grande) em cada município, microrregião e mesorregião

(ha) - Área das propriedades segundo o tamanho (se pequena, média ou grande) em cada município, microrregiäo e mesorregiăo

$\%$ - Proporção de cada categoria de propriedade (se pequena, média ou grande) com relaçăo à quantidade total de propriedades e à área total das propriedades expressa em ha

* - Dados extremamente disparatados (valores para mais ou para menos), com fortes indícios de erro

Anexo: 0 leitor que se interessar por uma informaçăo mais generalizada, pode recorrer à representação dos dados por microrregiäo, conforme é mostrado na matriz ponderada - na verdade, trata-se de uma coleçăo de diagramas ponderados de forma matricial - (5), em que se enfatiza a predominância deste ou daquele tipo de propriedade segundo os valores porcentuais do número de propriedades e das áreas de cada uma delas em cada microrregiāo. 


\begin{tabular}{|c|c|c|c|c|c|c|c|c|c|c|c|c|c|c|c|c|c|}
\hline \multicolumn{18}{|c|}{ QUADRO RESUMO DOS IMÓVEIS RURAIS CADASTRADOS NO INCRA POR MUNICÍPIO, MICRORREGIÃO E MESORREGIÃO } \\
\hline \multirow[t]{2}{*}{ Município } & \multirow{2}{*}{$\begin{array}{c}\text { Módulo } \\
\text { (ha) }\end{array}$} & \multirow[t]{2}{*}{ QT } & \multirow{2}{*}{$\begin{array}{r}\text { Prop } \\
\text { (ha) }\end{array}$} & \multirow{2}{*}{$\begin{array}{l}\text { Mun } \\
\text { (ha) }\end{array}$} & \multirow{2}{*}{$\begin{array}{c}\% / \\
\text { Mun }\end{array}$} & \multicolumn{4}{|c|}{ Pequena Propriedade } & \multicolumn{4}{|c|}{ Média Propriedade } & \multicolumn{4}{|c|}{ Grande Propriedade } \\
\hline & & & & & & Q & $\%$ & (ha) & $\%$ & Q & $\%$ & (ha) & $\%$ & Q & $\%$ & (ha) & $\%$ \\
\hline S.M. DO ARAGUAIA & 61,4 & 3.815 & 2.260 .715 & 2.438.138 & 92,7 & 2.011 & 52,7 & 184.380 & 8,1 & 1.098 & 28,8 & 551.420 & 24,4 & 706 & 18,4 & 1.524.915 & 67,5 \\
\hline RIO VERMELHO & 46,7 & 5.883 & 1.930 .775 & 2.020 .618 & 95,6 & 3.958 & 67,3 & 203.433 & 10,6 & 1.294 & 22,0 & 462.262 & 23,9 & 631 & 10,7 & 1.265.080 & 65,5 \\
\hline ARAGARÇAS & 47,1 & 3.452 & 1.145.117 & 1.105.385 & 103,6 & 2.245 & 65,0 & 157.539 & 13,8 & 823 & 23,8 & 305.728 & 26,7 & 384 & 11,2 & 681.850 & 59,5 \\
\hline NW GOIANO & 52,6 & 13.150 & 5.336 .607 & 5.564 .141 & 95,9 & 8.214 & 62,5 & 545.352 & 10,2 & 3.215 & 24,4 & 1.319 .410 & 24,7 & 1.721 & 13,1 & 3.471 .845 & 65,1 \\
\hline PORANGATU & 54,5 & 12.368 & 2.657 .279 & 3.517.186 & 75,6 & 9.235 & 74,7 & 691.916 & 26,0 & 2.427 & 19,6 & 1.021 .522 & 38,5 & 706 & 5,7 & 943.841 & 35,5 \\
\hline CH. DOS VEAD. & 72,5 & 2.914 & 1.715 .816 & 2.133 .751 & 80,4 & 1.786 & 61,6 & 176.116 & 10,3 & 692 & 23,9 & 402.681 & 23,5 & 420 & 14,5 & 1.137.019 & 66,2 \\
\hline NORTE GOIANO & 63,5 & 15.282 & 4.373 .095 & 5.650 .937 & 77,4 & 11.021 & 72,2 & 868.032 & 19,8 & 3.119 & 20,4 & 1.424 .203 & 32,6 & 1.126 & 7,4 & 2.080 .860 & 47,6 \\
\hline VÄODO PARANÃ & 70,0 & 4.373 & 1.660 .299 & 1.736 .882 & 95,6 & 3.284 & 75,1 & 222.375 & 13,3 & 679 & 15,5 & 358.007 & 21,6 & 437 & 10,0 & 1.079 .917 & 65,1 \\
\hline ENT. DE BRA. & 38,3 & 15.527 & 3.181.868 & 3.813 .158 & 83,4 & 11.071 & 71,3 & 509.516 & 16,0 & 3.159 & 20,3 & 926.445 & 29,1 & 1.296 & 8,4 & 1.745 .707 & 54,9 \\
\hline LESTE GOIANO & 50,2 & 19.900 & 842.167 & 5.550 .040 & 87,3 & 14.355 & 70,8 & 731.891 & 15,2 & 3.838 & 19,2 & 1.284 .452 & 26,5 & 1.733 & 8,6 & 2.825 .624 & 58,2 \\
\hline CERES & 26,6 & 11.621 & 1.208 .477 & 1.316 .312 & 83,1 & 9.027 & 77,7 & 296.565 & 24,5 & 1.979 & 17,0 & 377.603 & 31,2 & 615 & 5,3 & 534.309 & 44,3 \\
\hline ANÁPOLIS & 21,1 & 10.606 & 711.745 & 827.174 & 87,2 & 8.496 & 80,1 & 219.437 & 30,4 & 1.713 & 16,2 & 257.043 & 35,6 & 397 & 3,7 & 245.265 & 34,0 \\
\hline GOIÂNIA & 21,3 & 8.315 & 524.266 & 682.480 & 77,0 & 6.679 & 81,4 & 191.128 & 36,5 & 1.243 & 14,9 & 193.704 & 36,9 & 304 & 3,7 & 139.434 & 26,6 \\
\hline ANICUNS & 23,8 & 6.253 & 505.732 & 546.470 & 92,2 & 5.020 & 80,3 & 149.738 & 29,6 & 984 & 15,7 & 173.168 & 34,2 & 249 & 4,9 & 182.826 & 36,2 \\
\hline IPORÁ & 26,8 & 4.755 & 673.406 & 707.966 & 95,2 & 3.349 & 70,4 & 139.604 & 20,7 & 1.049 & 22,1 & 213.290 & 31,7 & 357 & 7,5 & 320.512 & 47,6 \\
\hline CENTRO GOIANO & 23,8 & 41.550 & 3.633 .626 & 4.080 .402 & 89,1 & 32.571 & 78,6 & 996.472 & 27,4 & 6.968 & 16,8 & 1.214 .808 & 33,4 & 1.922 & 4,6 & 1.422 .346 & 39,2 \\
\hline SW GOIANO & 42,3 & 15.258 & 5.661 .895 & 5.611 .152 & 100,9 & 8.211 & 54,3 & 537.988 & 9,5 & 4.629 & 30,3 & 1.567 .980 & 27,7 & 2.338 & 15,4 & 3.555 .927 & 62,8 \\
\hline QUIRINÓPOLIS & 31,0 & 5.343 & 1.554 .809 & 1.606 .811 & 99,6 & 2.973 & 55,6 & 143.174 & 9,2 & 1.479 & 27,7 & 365.903 & 23,5 & 891 & 16,7 & 1.045 .732 & 67,3 \\
\hline RIO DOS BOIS & 26,1 & 7.817 & 1.344 .400 & 1.360 .867 & 98,9 & 5.406 & 56,2 & 187.028 & 13,9 & 1.667 & 21,3 & 347.947 & 25,9 & 744 & 9,5 & 809.425 & 60,2 \\
\hline MEIAPONTE & 33,1 & 12.868 & 1.934 .641 & 2.117 .556 & 91,4 & 8.891 & 69,1 & 422.919 & 21,9 & 3.134 & 24,4 & 736.862 & 38,1 & 843 & 6,5 & 774.860 & 40,0 \\
\hline PIRES D0 RI0 & 33,0 & 7.932 & 857.239 & 941.839 & 91,0 & 6.199 & 78,2 & 276.402 & 32,2 & 1.463 & 18,4 & 351.385 & 41,0 & 270 & 3,4 & 229.452 & 26,8 \\
\hline CATALÃ̃O & 39,4 & 7.376 & 1.378 .275 & 1.520 .684 & 90,6 & 5.194 & 70,4 & 285.790 & 20,7 & 1.683 & 22,8 & 489.789 & 35,5 & 499 & 6,8 & 602.696 & 43,8 \\
\hline SUL GOIANO & 34,9 & 56.594 & 12.731 .259 & 13.158.909 & 96,8 & 36.874 & 65,3 & 1.853 .301 & 14,6 & 14.055 & 24,8 & 3.859 .866 & 30,3 & 5.585 & 9,9 & 7.018.092 & 55,1 \\
\hline ESTADO & 37,9 & 146.476 & 30.916 .554 & 34.004 .429 & 90,8 & 103.035 & 70,5 & 4.995 .048 & 16,1 & 31.195 & 21,3 & 9.102 .739 & 29,4 & 12.087 & 8,2 & 16.818 .767 & 54,4 \\
\hline
\end{tabular}

CONVENÇÕES ADOTADAS NESTA TABELA

Módulo - Módulo fiscal em cada município, microrregiäo e mesorregião expresso em hectares (ha)

QT - Quantidade total de propriedades em cada município, microrregiäo e mesorregiăo

Mun - Área do município expressa em hectares (ha)

\% / - Proporç̧̃o da área das propriedades com relação à área do município

Q- Quantidade de propriedades segundo o tamanho (se pequena, média ou grande) em cada município, microrregião e mesorregiăo

(ha) - Área das propriedades segundo o tamanho (se pequena, média ou grande) em cada município, microrregião e mesorregião

\% - Proporção de cada categoria de propriedade (se pequena, média ou grande) com relaç̧a à quantidade total de propriedades eà área total das propriedades expressa em ha

* - Dados extremamente disparatados (valores para mais ou para menos), com fortes indícios de erro

Anexo: 0 leitor que se interessar por uma informação mais generalizada, pode recorrer à representaçăo dos dados por microrregiăo, conforme é mostrado na matriz ponderada - na verdade, trata-se de uma coleçăo de diagramas ponderados de forma matricial - (5), em que se enfatiza a predominância deste ou daquele tipo de propriedade segundo os valores porcentuais do número de propriedades e das áreas de cada uma delas em cada microrregiāo. 


\section{Notas}

1. Aliás, observando-se atentamente os dados, constata-se que houve um erro de anotação, ou por parte do órgão responsável pelos dados - INCRA - ou pelo órgão que os reproduziu - SEPLAN-SEPIN -, pois, em todos os municípios as propriedades foram especificadas da seguinte forma: - Pequena Propriedade: 0 até 4 ha (em vez de 0 até 4 módulos) - Média propriedade: +4 até 15 ha (em vez de +4 até 15 módulos) - Grande propriedade: mais de 15 ha (em vez de mais de 15 módulos). Na verdade, não há propriedade com zero hectare de área. Ela deve ter um mínimo de superfície, caso contrário não existiria. Então, a anotação teria que ser pelo menos assim: "+ de 0 até 4 módulos, ou simplesmente "até 4 módulos”.

2. Em 2006, o último recenseamento agropecuário realizado pelo IBGE (BRASIL, 2006) informava que entre aquele ano e 1996 houve uma reviravolta no campo goiano: enquanto, por um lado, o número total de estabelecimentos rurais passava de 111.791 em 1996 para 136.244 em 2006 (aumento de 21,9\%), por outro, a área total encolheu, passando de 27.472.648 ha para 24.983.002 ha (diminuição de cerca de 10\%). Como se explica isto? Para onde e para quem foram parar 2.489.965 ha (24.899,65 quilômetros quadrados) de terras que não mais fazem parte das propriedades rurais do estado? Das duas hipóteses, uma deve ser verdadeira: ou o IBGE se enganou na realização da tabela, ou os dados do censo anterior (1995, divulgados em 1996) foram superestimados, pois, de lá para cá, em consequência da busca de alternativas energéticas baseadas na produção de etanol, sobretudo a partir da cana, sabe-se que mais áreas foram incorporadas às propriedades rurais e ao processo produtivo.

\section{Referências}

BRASIL. Presidência da República. Casa Civil. Lei n. 8.629, de 25 de fevereiro de 1993. In: http://www.planalto.gov.br/ccivil_03/leis/L8629.htm. Acesso em: 20 out. 2011

. Presidência da República. Casa Civil. Lei n. 10.267, de 28 de agosto de 2001. In: http://www.planalto.gov.br/ccivil_03/leis/LEIS_2001/L10267.htm. Acesso em: 25 out. 2011

. Censo agropecuário 2006. Rio de Janeiro: IBGE, 2007.

. Ministério do Desenvolvimento Agrário. Agricultura familiar no Brasil e o censo agropecuário, 2006. Brasília: Ministério do Desenvolvimento Agrário, 2010.

GOIÁS. Anuário estatístico do estado de Goiás - 2003. Goiânia: SEPLAN, 2003.

. Anuário estatístico do estado de Goiás - 2005. Goiânia: SEPLAN, 2005.

GOMES, Horiestes, TEIXEIRA NETO, Antônio; SALES, Altair. Geografia: Goiás/ Tocantins. Goiânia: Ed. UFG, 2004.

INCRA [2011]. In: http://incra.gov.br/portal/index.php?option=com_content\&vie $\mathrm{w}=$ category\&id $=273 \&$ layout $=$ blog\&Itemid $=291$. Acesso em 20 out. $2 \overline{0} 11$. 
TEIXEIRA NETO, Antônio. Formação territorial: considerações sobre alguns aspectos geográficos, históricos e políticos. Boletim Goiano de Geografia, v. 2, n. $2,1982$.

. Os caminhos de ontem e de hoje em direção a Goiás-Tocantins. Boletim Goiano de Geografia, v. 21, n. 1, 2001.

Antonio Teixeira Neto - Doutor em Geografia e Cartografia pela Université de Paris VII, Pós-Doutorado pela Ecole des Hautes Etudes en Sciences Sociales (Paris).

Recebido para publicação em julho de 2011

Aceito para publicação em outubro de 2011 